\title{
Comparative Wood Anatomy of the Primuloid Clade (Ericales s.1.)
}

\author{
Frederic Lens, ${ }^{1,3}$ Steven Jansen, ${ }^{2,1}$ Pieter Caris, ${ }^{1}$ Liesbet Serlet, ${ }^{1}$ and Erik Smets ${ }^{1}$ \\ ${ }^{1}$ Laboratory of Plant Systematics, Institute of Botany and Microbiology, Katholieke Universiteit Leuven, \\ Kasteelpark Arenberg 31, B-3001 Leuven, Belgium

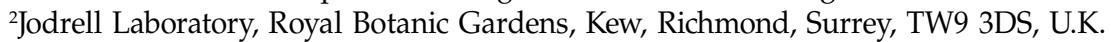 \\ ${ }^{3}$ Author for Correspondence (frederic.lens@bio.kuleuven.ac.be)
}

\author{
Communicating Editor: Paul S. Manos
}

\begin{abstract}
Aвstract. The wood structure of 78 species from 27 genera representing the woody primuloids (Maesaceae, Myrsinaceae, and Theophrastaceae) was investigated using light microscopy (LM) and scanning electron microscopy (SEM). Results indicated that the ray structure, the nature of mineral inclusions, and the occurrence of breakdown areas in rays can be used to separate the three primuloid families from each other. Within Ericales, the presence of exclusively multiseriate rays is synapomorphic for Myrsinaceae and Theophrastaceae, and the occurrence of breakdown areas in rays is synapomorphic for Myrsinaceae. Within Myrsinaceae, the wood structure of the mangrove genus Aegiceras differs because it has short vessel elements that are storied, non-septate fibers, a combination of low uni- and multiseriate rays, and multiseriate rays with exclusively procumbent body ray cells. The aberrant wood anatomy of Coris and Lysimachia can be explained by their secondary woodiness. Within Theophrastaceae, Clavija and Theophrasta can be distinguished from Bonellia, Jacquinia, and Deherainia. The recent division of Jacquinia s.l. into Jacquinia s.s. and Bonellia is supported by a difference in mineral inclusions.
\end{abstract}

The primuloid clade is one of the few groups within the newly circumscribed Ericales that is well supported based on molecular sequence data (Anderberg et al. 2002; Bremer et al. 2002). The clade comprises five families, Maesaceae, Myrsinaceae, Primulaceae, Samolaceae, and Theophrastaceae, and about 65 genera and 2600 species (Kubitzki 2004). More than half of the primuloid representatives are woody, mostly small to medium-sized trees or shrubs, and sometimes lianas. The genus Samolus L. (Samolaceae), all Primulaceae, and a few Myrsinaceae taxa, representing ca. 20 genera and 1100 species, are herbs and therefore omitted from this study. The distribution of woody primuloids is mainly tropical: Myrsinaceae are pantropical with several taxa extending to tropical montane habitats, Theophrastaceae are restricted to the neotropics, and Maesaceae are concentrated in the palaeotropics. Primulaceae, on the other hand, grow in the temperate regions of the Northern Hemisphere, and Samolaceae have their main distribution in saline habitats of the Southern Hemisphere (Källersjö et al. 2000).

All representatives of the primuloid clade have long been placed in the former Primulales (Pax 1889; Mez $1902,1903)$, which were characterized by a set of floral characteristics: (1) sympetalous flowers with functional stamens as many as and opposite to the corolla lobes, (2) a compound, mainly hypogynous ovary with one style, and (3) few to many tenuinucellate, usually anatropous, bitegmic ovules set on a free-central to basal placenta (Cronquist 1988). Family concepts within the primuloid clade have changed considerably during the last 10 years. Based on molecular and morphological data, the genus Maesa Forssk. was removed from Myrsinaceae and elevated to family level (Anderberg and Ståhl 1995; Anderberg et al. 1998, 2000; Caris et al. 2000; Ståhl and Anderberg 2004a). Now, Maesaceae are considered sister to all other primuloids (Källersjö et al. 2000). In addition, Källersjö et al. (2000) and Anderberg et al. (2001) proposed to place the former Primulaceae genera Ardisiandra Hook. f., Anagallis L., Asterolinon Hoffmannsegg \& Link, Coris L., Cyclamen L., Glaux L., Lysimachia L., Pelletiera A. St.-Hil., Stimpsonia C. Wright ex A. Gray, and Trientalis L. within the sister family Myrsinaceae. Furthermore, another genus of Primulaceae, Samolus, was placed as sister to the remaining Theophrastaceae by the same authors. The monophyly of the family Theophrastaceae excluding Samolus is morphologically well supported (Ståhl 2004a, b). Also floral ontogenetic work supported the family level for Samolus as sister to Theophrastaceae (Caris and Smets 2004). These two families in turn are sister to the Primulaceae-Myrsinaceae clade (Källersjö et al. 2000).

Besides these renewed family concepts, generic realignments within primuloid families were proposed. For instance, the monophyly of various Myrsinaceae genera is still a matter of dispute (Ståhl and Anderberg 2004b), and recent molecular sequence data from Theophrastaceae suggest that the orange-red flowered Jacquinia L. species together with Jacquinia paludicola Standl. and J. longifolia Standl. should be recognized as a separate genus Bonellia Colla in order to maintain the monophyly of the morphologically well supported genera Deherainia Decaisne and Votschia Ståhl (Källersjö and Ståhl 2003; Ståhl and Källersjö 2004).

The wood anatomy of primuloid families is poorly known. The most detailed overview was presented by Metcalfe and Chalk (1950), based on nine Myrsinaceae genera, four Theophrastaceae genera, and Maesa. Other noteworthy studies that included a restricted number of primuloids were presented by Moll and Janssonius (1926), Williams (1936), Détienne et al. (1982), Suzuki 
and Noshiro (1988), Ogata and Kalat (1997), and Sosef et al. (1998).

This work aims to present a detailed wood anatomical overview of Maesaceae, Myrsinaceae, and Theophrastaceae, using light microscopy (LM) and scanning electron microscopy (SEM). The anatomical variation observed will be compared with the recent familial and generic realignments within the primuloid clade, taking ecological and physiological aspects into account. In addition, some selected wood features will be plotted on a simplified molecular tree to trace evolutionary patterns. This study also addresses the possibilities of secondary woodiness within primuloids, since Anderberg et al. (2001) suggested that the ancestor of the Samolaceae-Theophrastaceae-PrimulaceaeMyrsinaceae clade could be herbaceous.

\section{MATERIALS AND METHODS}

In total, 92 wood specimens representing 78 species and 27 genera were investigated using LM and SEM (Appendix 1). Twenty one genera of Myrsinaceae sensu Ståhl and Anderberg (2004b), five genera of Theophrastaceae (including Bonellia) and the genus Maesa were included.

Wood sections of about $25 \mu \mathrm{m}$ thick were cut using a sledge microtome. After bleaching, staining and dehydrating, the tissues were mounted in euparal. Preparations for macerations and SEM are according to Jansen et al. (1998). The wood anatomical terminology follows the "IAWA list of microscopic features for hardwood identification" (IAWA Committee 1989), except for the term 'breakdown areas in rays' which is illustrated by Aegiceras Gaertn. in the CSIRO family key for hardwood identification (Ilic 1987). According to Webber (1938), these structures are 'intercellular cavities possibly of normal occurrence' and were called 'gum cysts' by Panshin (1932) or 'schizogenous secretory cavities' by Metcalfe and Chalk (1950). Breakdown areas in rays often contain orange to dark brown substances including neutral lipids and hydrobenzoquinones, a typical compound that is observed in five Myrsinaceae genera and in Maesa. Hydrobenzoquinones are also present in epithelial cells surrounding secretory cavities in both vegetative and reproductive tissues, and in groups of cells in the placental epidermis, and possibly function as a defense mechanism against insects (Otegui et al. 1997).

Wood features were optimized on trees using the program MacClade 4.04 (Maddison and Maddison 2002).

\section{RESULTS}

The material studied is presented according to the classification of Källersjö et al. (2000). For each genus examined the number of species studied is provided before the slash mark and the total number of species in the genus follows the slash mark. Numbers between brackets are extreme values. A summary of the results is presented in Table 1.

Maesaceae. Taxa studied: Maesa 5/100 (Fig. 1). Growth ring boundaries absent or distinct. Diffuse-porous. Vessels usually solitary and in short radial multiples of 2-4 (Figs. 1A-B; up to 8 cells in Uw 15537), or exceptionally in vessel clusters of 3-5 cells; vessel outline mostly angular. Vessel perforation plates simple (Fig. 1C), but few scalariform perforations with 5-7 bars in M. lanceolata. Intervessel pits alternate (Fig. 1D), 4-6 $\mu \mathrm{m}$ in size, non-vestured. Vessel-ray pits similar to intervessel pits in shape and size, sometimes having scalariform pits with distinct borders in M. indica, $M$. ramentacea, and $M$. schweinfurthii; vessel ray-pits mainly scalariform with strongly reduced to nearly simple pits in M. lanceolata (Fig. 1H) and M. macrothyrsa, 10$30 \mu \mathrm{m}$ in size. Helical sculpturing indistinctly present throughout body of vessel elements, or restricted to tails of vessel elements. Tangential diameter of vessels (30-)40-100(-120) $\mu \mathrm{m},(18-) 20-90(-101)$ vessels per $\mathrm{mm}^{2}$, vessel elements (330-)460-850(-1070) $\mu \mathrm{m}$ long. Tracheids absent. Fibers septate, thin- or thin- to thickwalled, (520-)870-1270(-1560) $\mu \mathrm{m}$ long, with simple to minutely bordered pits concentrated in radial walls, pit borders 2-3 $\mu \mathrm{m}$ in diameter. Axial parenchyma scanty paratracheal (Figs. 1A, B); 2-4 cells per parenchyma strand. Uniseriate rays always present (Figs. 1E, F), (160-)330-1430(-2100) $\mu \mathrm{m}$ high, consisting of upright cells, $0(-2-) 6$ rays per $\mathrm{mm}$. Multiseriate rays $2-5(-$ 8-)seriate, (200-)470-2590(-7000) $\mu \mathrm{m}$ (and even more) high, $0(-4-) 6$ rays per $\mathrm{mm}$, consisting of predominantly procumbent body ray cells (Fig. 1G) or a mixture of procumbent, square, and upright body ray cells, and 1-4 upright rows of marginal ray cells; sheath cells present. Breakdown areas in rays absent. Gummy deposits in ray cells. Very few prismatic crystals in procumbent and upright ray cells of $M$. indica. Pith cells homogeneous.

Myrsinaceae. Taxa studied: Aegiceras 1/2, Afrardisia Mez 1/16, Ardisia Sw. 4/250, Badula Juss. 1/17, Coris 1/2, Ctenardisia Ducke 1/2, Cybianthus Mart. 7/150, Discocalyx (A. DC.) Mez 2/50, Embelia Burm. f. 4/130, Geissanthus Hook. f. 2/30, Grammadenia Benth. 2/7, Heberdenia Banks ex A. DC. 1/1, Lysimachia 2/150, Myrsine L. 3/4, Oncostemum A. Juss. 4/100, Parathesis (A. DC.) Hook. f. 6/75, Rapanea Aubl. 6/300, Stylogyne A. DC. 4/60, Synardisia (Mez) Lundell 1/1, Tapeinosperma Hook. f. 1/4, Wallenia Sw. 2/20 (Figs. 2-6). Growth ring boundaries generally indistinct, but distinct in Coris monspeliensis (Figs. 6A, B), Grammadenia parasitica (Fig. 2B), and in Oncostemum venulosum. Diffuse-porous. Vessels mostly solitary (Fig. 2A) and in short radial multiples of 2-4 (Figs. 2B-E, 6B-D; of up to 8 vessels in Ardisia cauliflora), few vessel clusters of 3-9 cells occasionally observed in most genera (Figs. 2F, H, 3A), exceptionally short tangential vessel multiples in Discocalyx and Embelia; vessel outline angular. Vessel perforation plates mostly simple (Figs. 3E, F, 6G, H), some scalariform perforations with 2-5 bars observed in $A f$ rardisia staudti, Ctenardisia stenobotrys, Discocalyx insignis, Stylogyne venezuelana, and Tapeinosperma nectandroides; vessel elements storied in Aegiceras (Fig. 4A). Intervessel pits alternate (Figs. 3G, H), 3-6 $\mu \mathrm{m}$ in size, non-vestured. Vessel-ray pits usually similar to intervessel pitting in shape and size, but mainly scalariform 


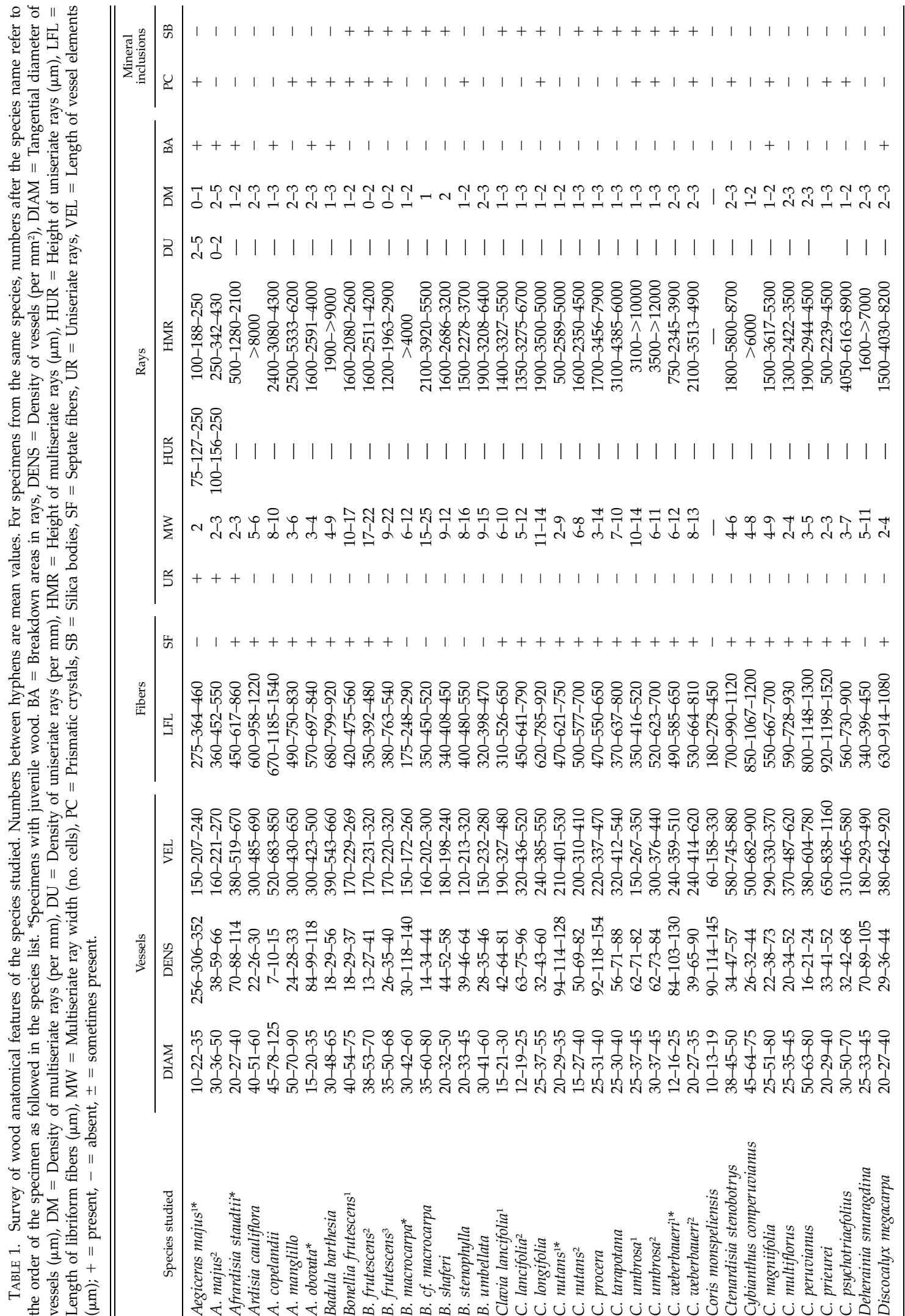




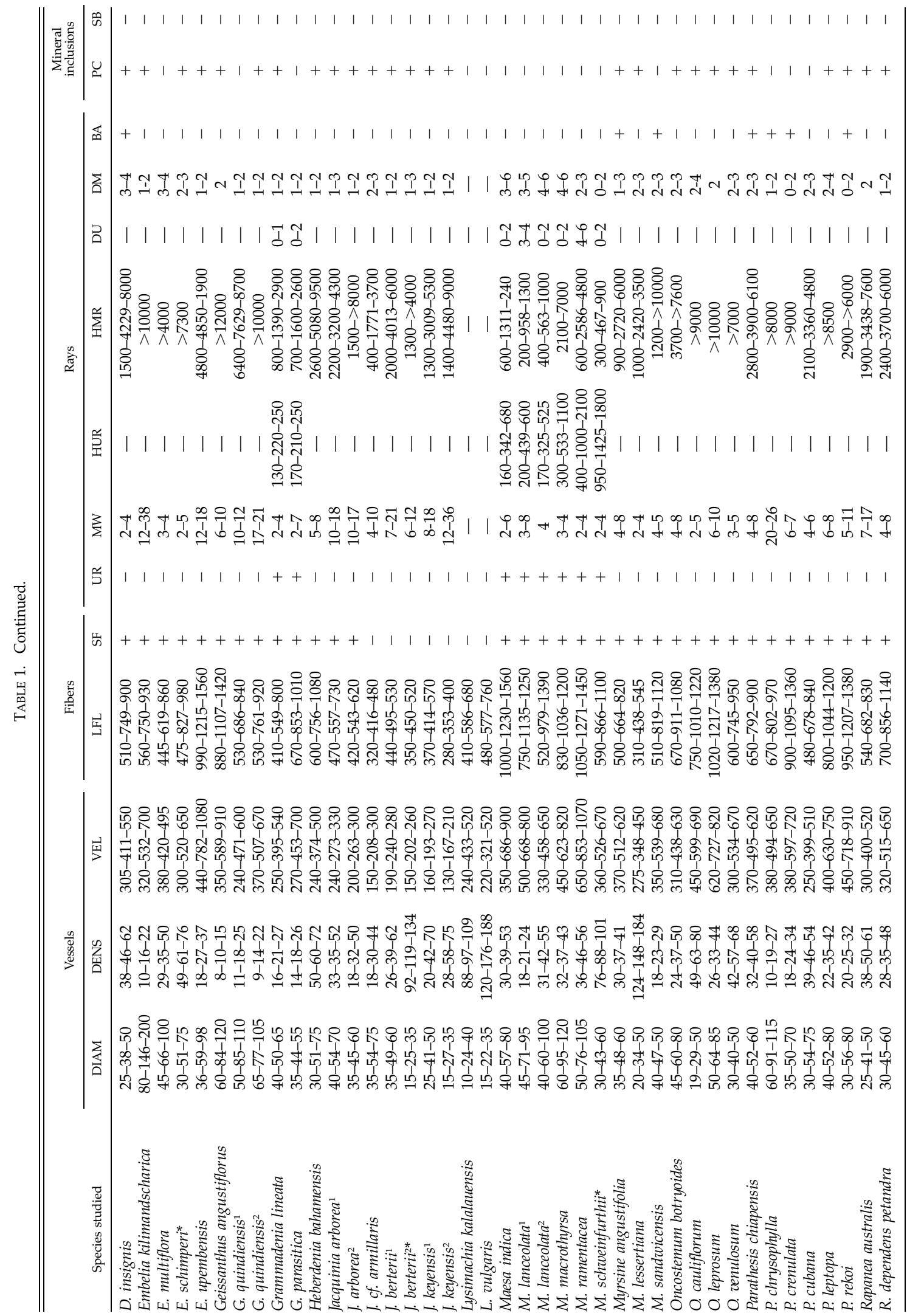




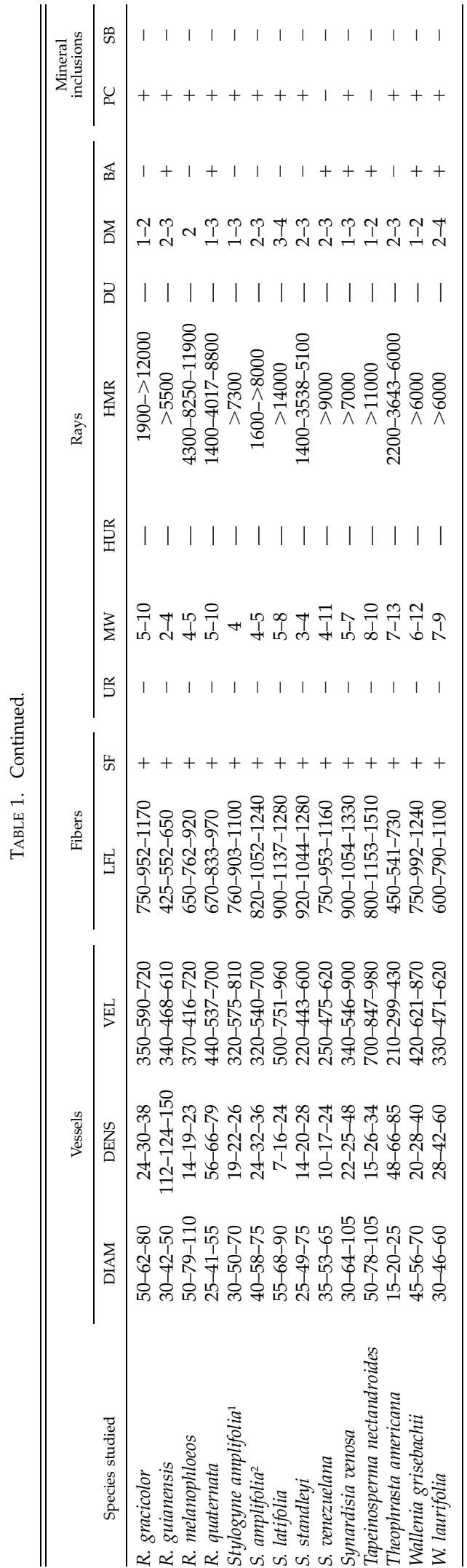

with distinct borders in Discocalyx, Embelia (Fig. 3I), Geissanthus, and Stylogyne, 10-30 $\mu \mathrm{m}$ in size. Helical sculpturing restricted to the tails of vessel elements in Ctenardisia stenobotrys. Tangential diameter of vessels (10-)10-150(-200) $\mu \mathrm{m},(7-) 10-310(-352)$ vessels per $\mathrm{mm}^{2}$, vessel elements (60-)160-850(-1160) $\mu \mathrm{m}$ long. Tracheids absent. Fibers usually septate (Figs. 5A, B) except in Aegiceras, Coris, and Lysimachia, thin- to thickwalled, (180-)280-1220(-1560) $\mu \mathrm{m}$ long, with simple to minutely bordered pits concentrated in both tangential and radial walls, pit borders $2-3 \mu \mathrm{m}$ in diameter, slitlike apertures sometimes elongated (Fig. 5B); fibers storied in Aegiceras (Fig. 4A). Axial parenchyma scanty paratracheal or vasicentric (Fig. 2), 2-8 cells per parenchyma strand. Sometimes undivided (fusiform) axial parenchyma cells observed in Ardisia, Badula, Cybianthus, Discocalyx, Embelia, Geissanthus, Oncostemum, Rapanea, and Stylogyne, fusiform cells 550-950 $\mu \mathrm{m}$ in length. Rays entirely absent in Coris and Lysimachia (Figs. 6E, F). Uniseriate rays clearly present in Aegiceras (Fig. 4A) and occasionally in Grammadenia (Fig. 4B), (75-)210-220(-250) $\mu \mathrm{m}$ high, consisting of upright cells, $0(-1-) 5$ rays per $\mathrm{mm}$. Multiseriate rays often 2-6-seriate (Figs. 4C, D), more than 10 cells wide in species of Embelia (Fig. 4E), Geissanthus (Fig. 4F), Parathesis, Rapanea, Stylogyne, and Wallenia, (100-)190-8250(-14000) $\mu \mathrm{m}$ (and even more) high, $0(-2-) 5$ rays per $\mathrm{mm}$, usually consisting of a mixture of procumbent, square and upright body ray cells (Figs. 5C, D) and a variable number of upright marginal ray cell rows; multiseriate rays often dissected (Fig. 4E), sheath cells present (Figs. 4C, D) except in Aegiceras. Groups of sclereids in rays concentrated near the end of a growth ring in Grammadenia parasitica (Fig. 4B) and Oncostemum venulosum. Breakdown areas in rays confined to one normal-sized (Figs. 3B, D) or enlarged cell (Figs. 4G, H), or to two or more adjacent ray cells (Figs. 3A, C, 4A, D, 5C, E, F); areas usually with a brown substance, in Parathesis chiapensis sometimes sclereid-like (Fig. $4 \mathrm{H}$ ), or areas empty giving the appearance of secretory ducts in $\mathrm{Ar}$ disia copelandii (Fig. 4D); breakdown areas in rays absent in species of Coris, Ctenardisia, Embelia, Geissanthus, Grammadenia, Heberdenia, Lysimachia, and Oncostemum. Gummy deposits present in ray cells. Single prismatic crystals (Figs. 5G, H) mostly present in nonchambered procumbent and upright ray cells, or exceptionally in chambered ray cells; sometimes styloids present in procumbent and upright ray cells. Pith including solitary or groups of sclereids, sometimes with secretory ducts in Ardisia (Fig. 2A), Embelia, Myrsine, and Oncostemum; pith containing many intercellular spaces in Lysimachia vulgaris (Fig. 6C).

Theophrastaceae. Taxa studied: Bonellia 5/22, Clavija Ruiz \& Pav. 10/50, Deherainia 1/2-3, Jacquinia 4/13, Theophrasta L. 1/2 (Figs. 7-9). Growth ring boundaries indistinct. Diffuse-porous. Vessels solitary and in short 

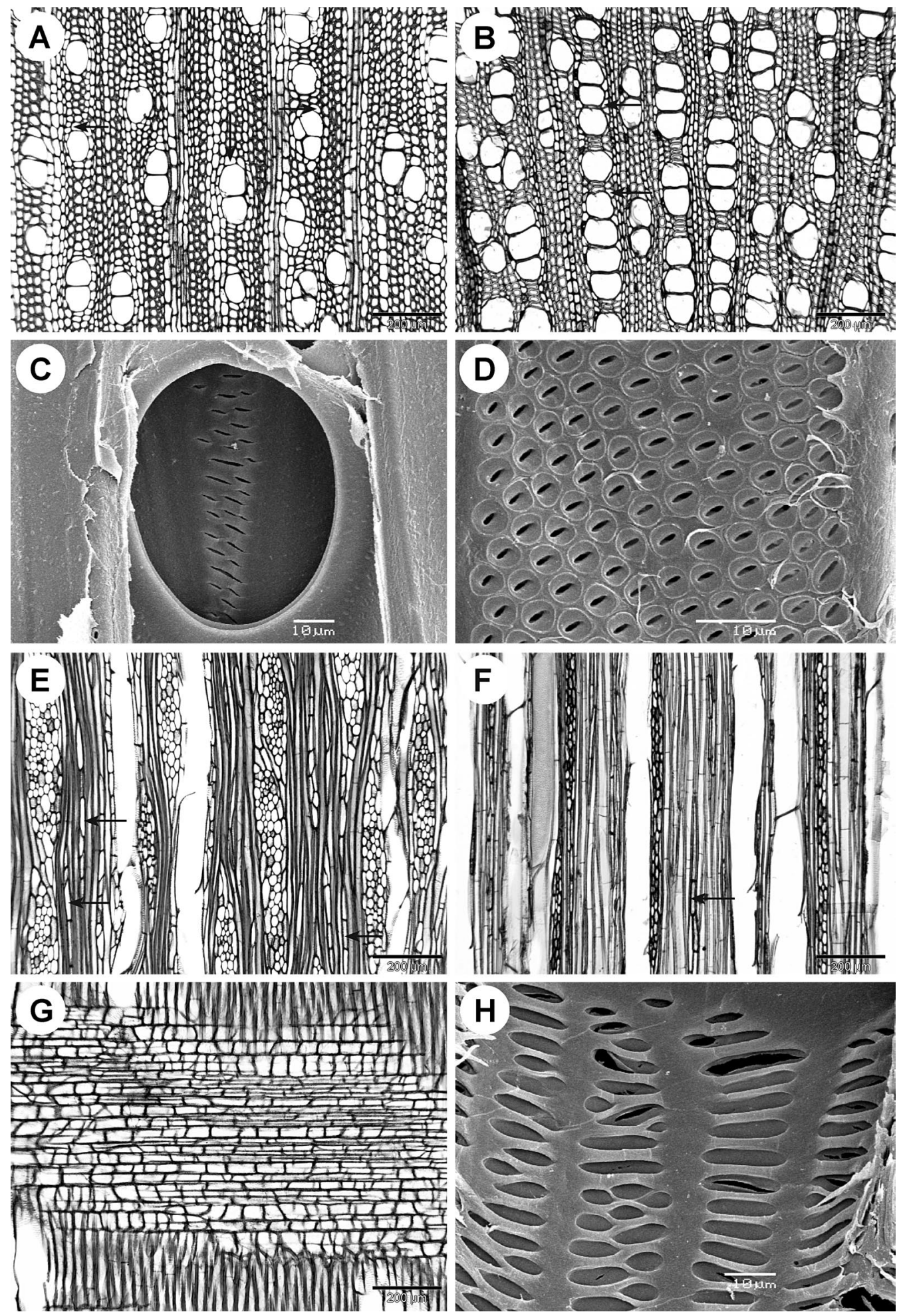

FIG. 1. Wood anatomical illustrations of Maesaceae (TS: transverse section, TLS: tangential section, RLS: radial section). A. Maesa lanceolata (Tw), TS, short radial vessel multiples and scanty paratracheal parenchyma (arrows). B. M. ramentacea, TS, short radial vessel multiples and scanty paratracheal parenchyma (arrows). C. M. ramentacea, RLS, simple vessel perforation. D. M. ramentacea, TLS, alternate vessel pitting. E. M. lanceolata (Tw), TLS, co-occurrence of uniseriate (arrows) and multiseriate rays. F. M. ramentacea, TLS, co-occurrence of uniseriate (arrow) and multiseriate rays. G. M. lanceolata (Tw), RLS, multiseriate ray showing mainly procumbent body ray cells. H. M. lanceolata $(\mathrm{Uw}), \mathrm{RLS}$, scalariform vessel-ray pitting. 

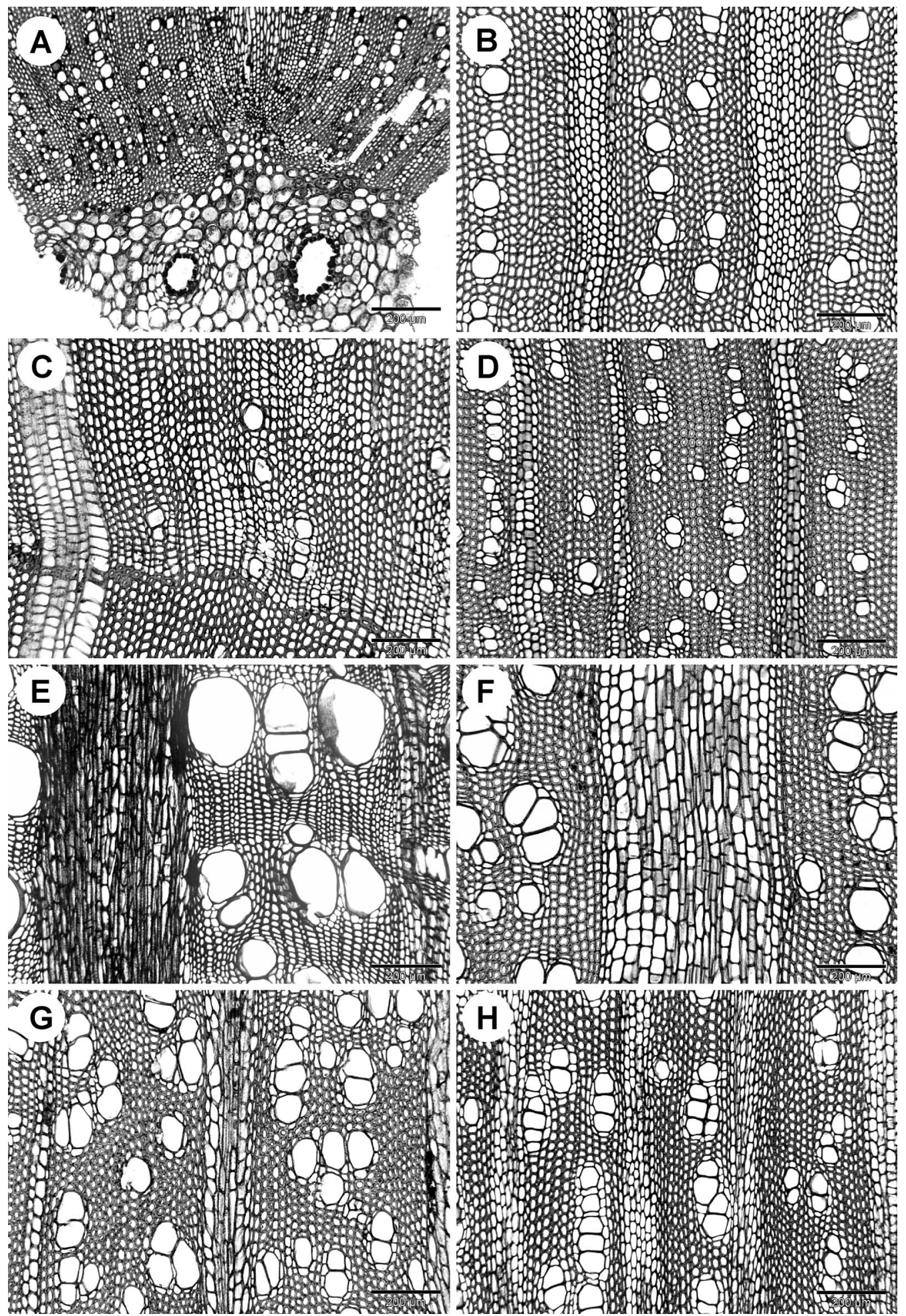

FIG. 2. Transverse sections of Myrsinaceae. A. Ardisia obovata, secretory ducts in pith. B. Stylogyne latifolia, vessels mostly solitary, scanty paratracheal parenchyma. C. Grammadenia parasitica, thick-walled sclereids at the end of a growth ring, scanty paratracheal parenchyma. D. Ctenardisia stenobotrys, vessels solitary or in short radial multiples, scanty paratracheal parenchyma. E. Embelia kilimandscharica, vessels solitary or in short radial multiples, scanty paratracheal parenchyma. F. Geissanthus quindiensis $(\mathrm{MADw})$, vessels solitary, in short radial multiples or in clusters, axial parenchyma scanty to vasicentric paratracheal. G. Oncostemum leprosum, vessels solitary, in short radial multiples or in clusters, axial parenchyma scanty paratracheal. H. Ardisia cauliflora, vessels in radial multiples or exceptionally in clusters, axial parenchyma scanty to vasicentric paratracheal. 

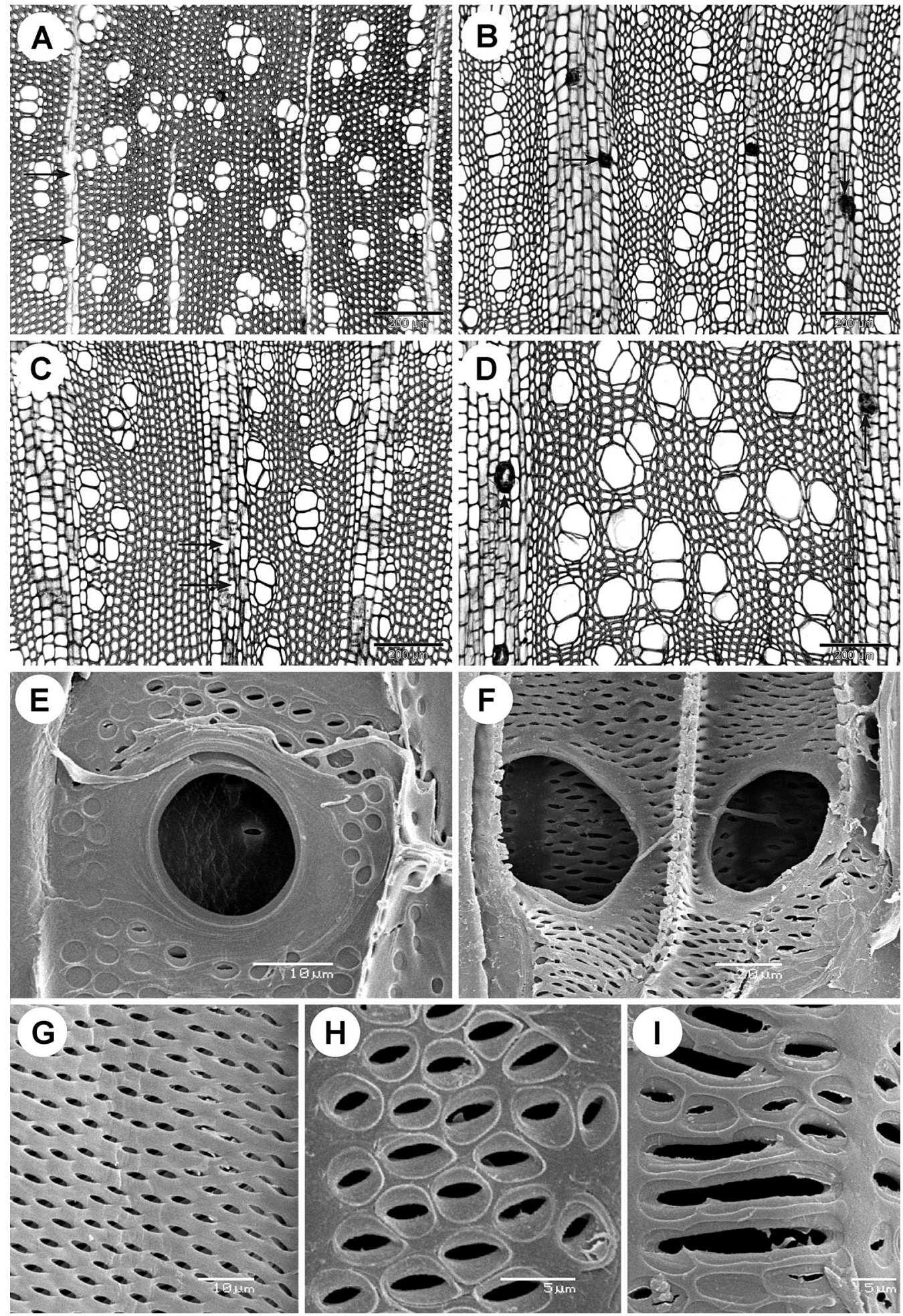

FIG. 3. Wood anatomy of Myrsinaceae showing breakdown areas in rays, vessel perforations, and vessel pitting. A. Aegiceras majus (MADw), TS, breakdown areas in rays (arrows). B. Wallenia laurifolia, TS, breakdown areas in rays (arrows). C. Badula barthesia, TS, breakdown areas in rays (arrows). D. Parathesis chrysophylla, TS, breakdown areas in rays (arrows). E. Cybianthus prieurei, RLS, one simple vessel perforation. F. Ardisia cauliflora, RLS, two simple vessel perforations. G. Geissanthus angustiflorus, TLS, alternate vessel pitting (inner pit apertures) shown from inside of vessel element. H. Stylogyne amplifolia (MADw), TLS, alternate vessel pitting (pit borders and outer pit apertures). I. Embelia kilimandscharica, RLS, tendency to scalariform vessel-ray pitting with distinct borders. 

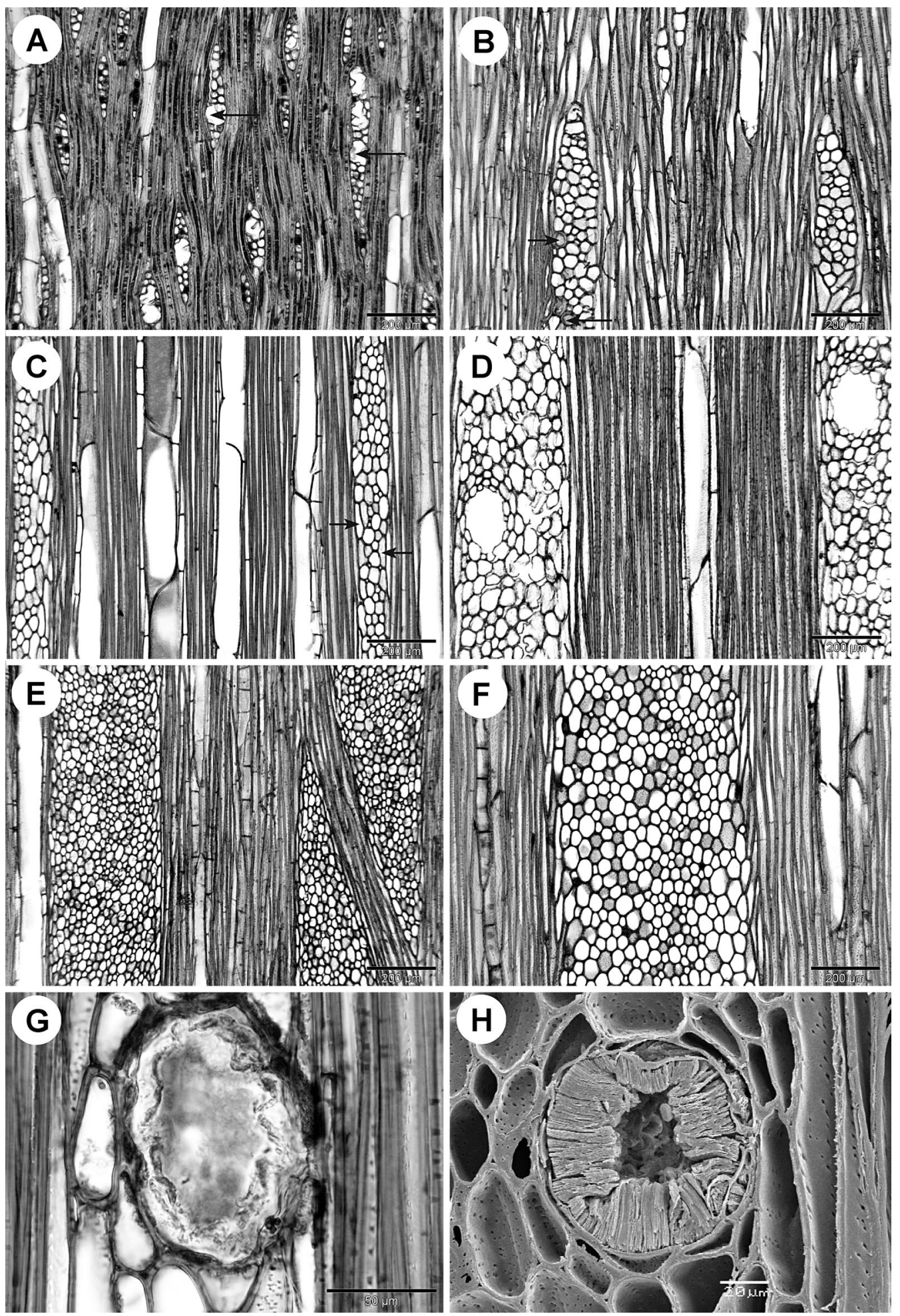

FIG. 4. Tangential sections of Myrsinaceae. A. Aegiceras majus (MADw), co-occurrence of uniseriate and narrow, low multiseriate rays with breakdown areas in rays (arrows). B. Grammadenia parasitica, multiseriate rays with few sclereids (arrows), occasionally uniseriate rays. C. Cybianthus comperuvianus, high multiseriate rays with indistinct sheath cells (arrows). D. Ardisia copelandii, empty breakdown ray areas. E. Embelia upembensis, wide multiseriate rays. F. Geissanthus quindiensis, wide multiseriate ray. G. Parathesis crenulata, detail of breakdown ray area, H. Parathesis chiapensis, detail of breakdown ray area containing a a sclereid-like substance. 

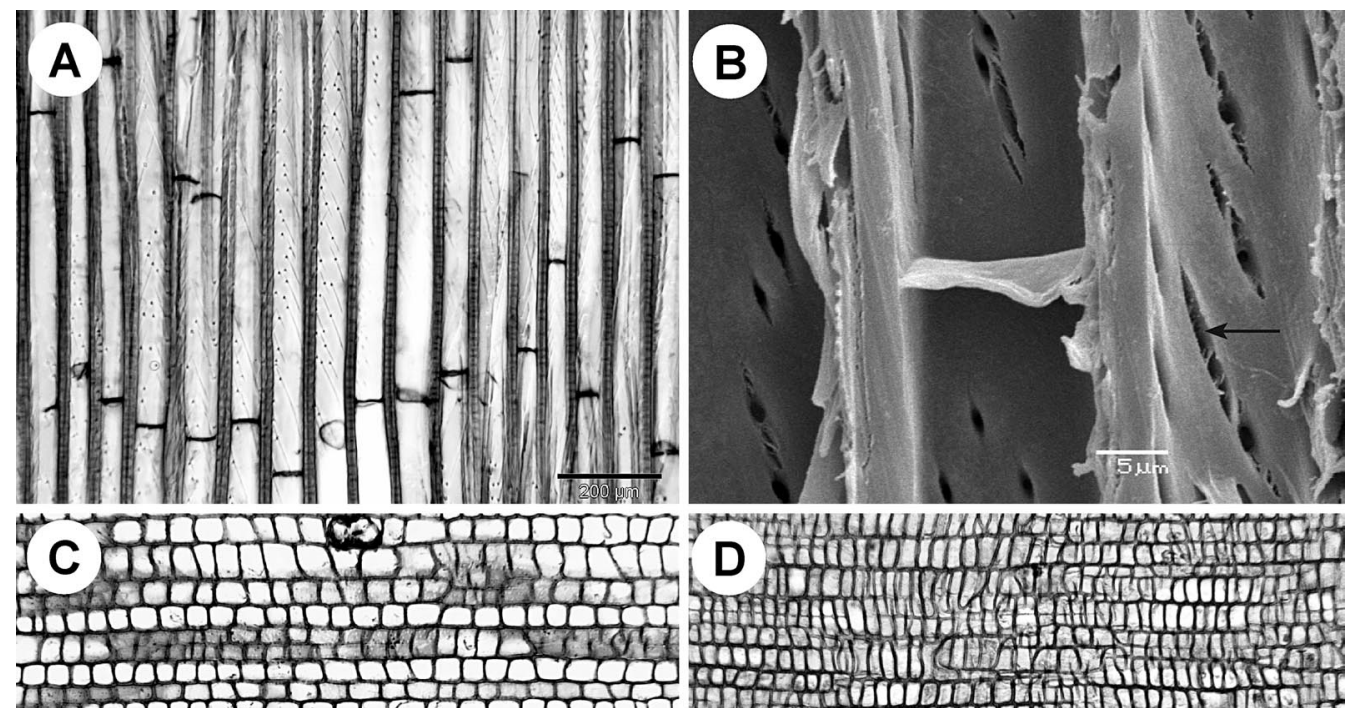

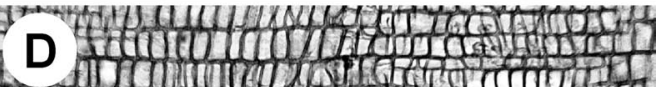
Din 1 I Hi2000

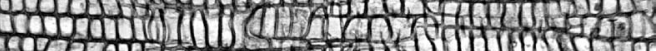

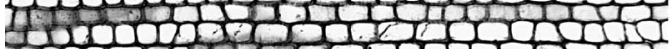

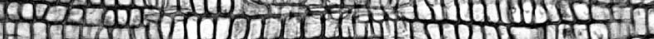

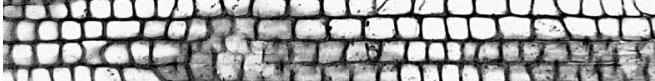
man

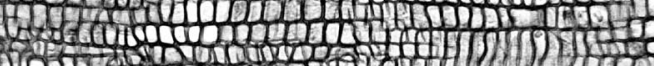
किसे की -

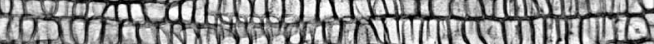

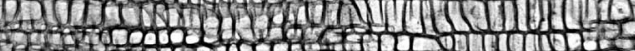

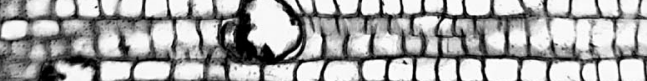
QfT) (2) 1210 (a)

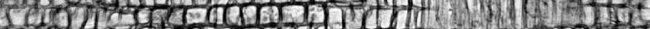

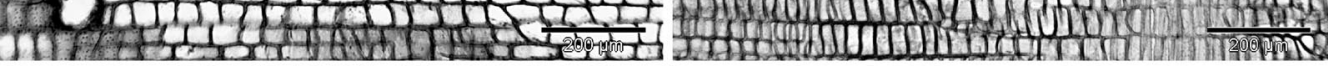
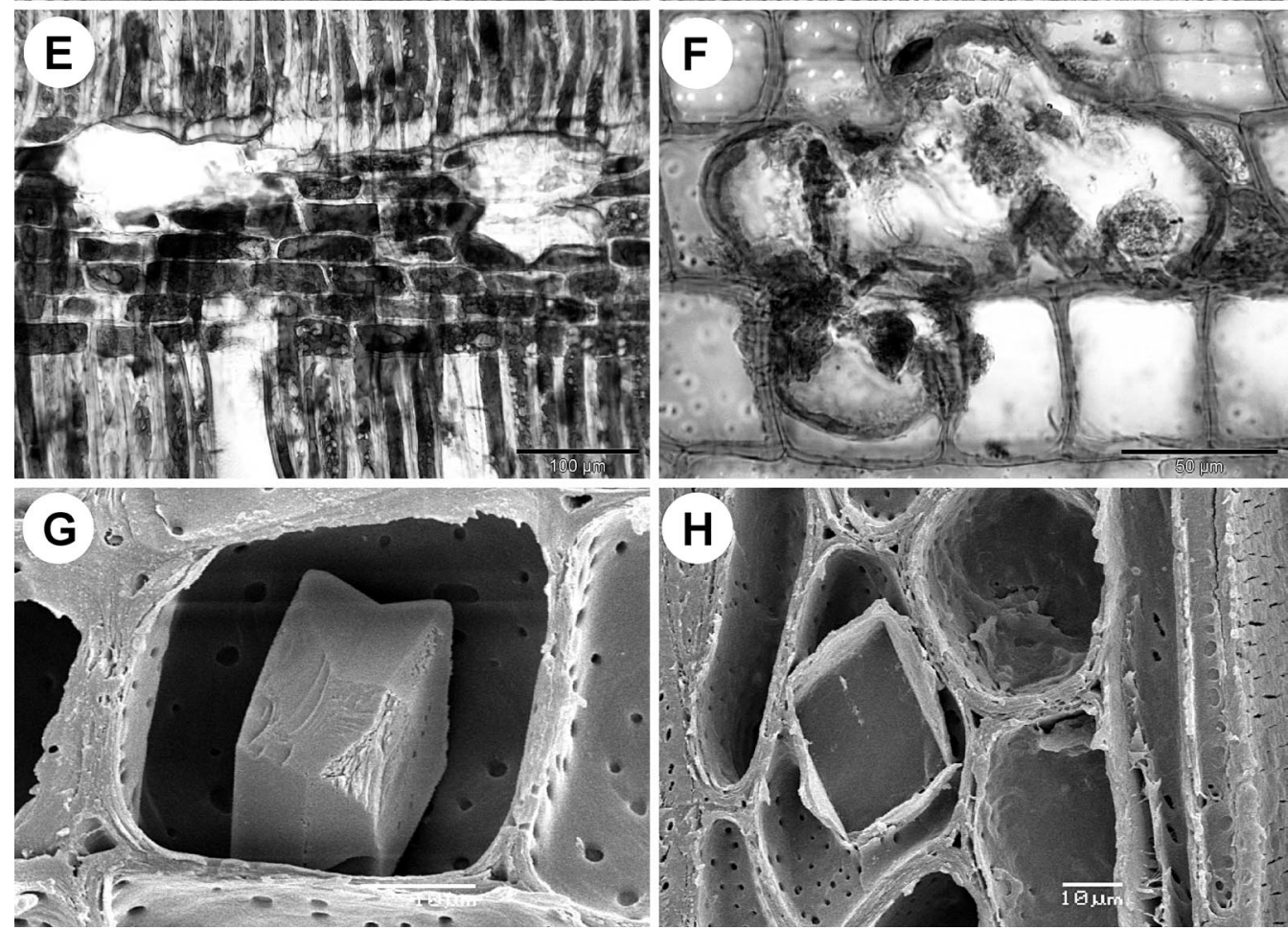

FIG. 5. Radial (A-G) and tangential (H) sections of Myrsinaceae. A. Stylogyne latifolia, septate libriform fibers. B. Parathesis chiapensis, detail of septate libriform fiber pits, slit-like apertures sometimes elongated (arrow). C. Cybianthus magniifolia, ray with procumbent, square and upright body ray cells, and breakdown areas in rays. D. Ctenardisia stenobotrys, ray with square to upright body ray cells. E. Aegiceras majus (MADw), ray with procumbent body ray cells and large breakdown areas in rays. F. Cybianthus magniifolia, detail of breakdown area in ray. G. Parathesis chiapensis, prismatic crystal in ray cell. H. Ctenardisia stenobotrys, prismatic crystal in ray cell. 

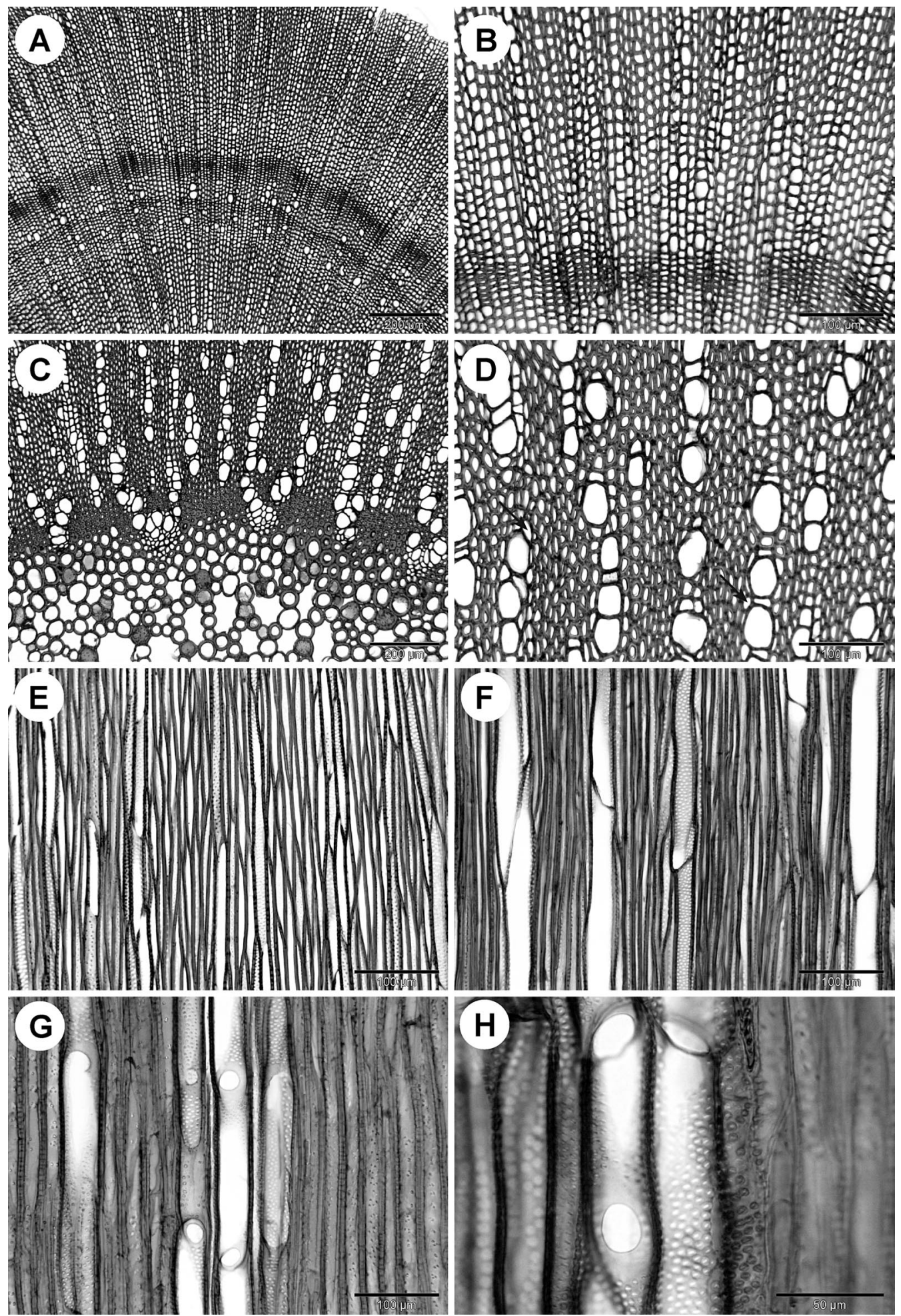

FIG. 6. Secondary woodiness in Myrsinaceae. A. Coris monspeliensis, TS, distinct growth rings and very narrow vessel elements. B. C. monspeliensis, TS, detail, narrow vessels solitary or in short radial multiples. C. Lysimachia vulgaris, TS, pith, primary xylem and first formed secondary xylem. D. L. vulgaris, TS, detail, vessels in solitary or in short radial multiples, axial parenchyma scanty paratracheal (arrows). E. C. monspeliensis, TLS, absence of rays. F. TLS, L. vulgaris, absence of rays. G. L. kalalauensis, RLS, simple vessel perforations. H. L. vulgaris, RLS, simple vessel perforations. 

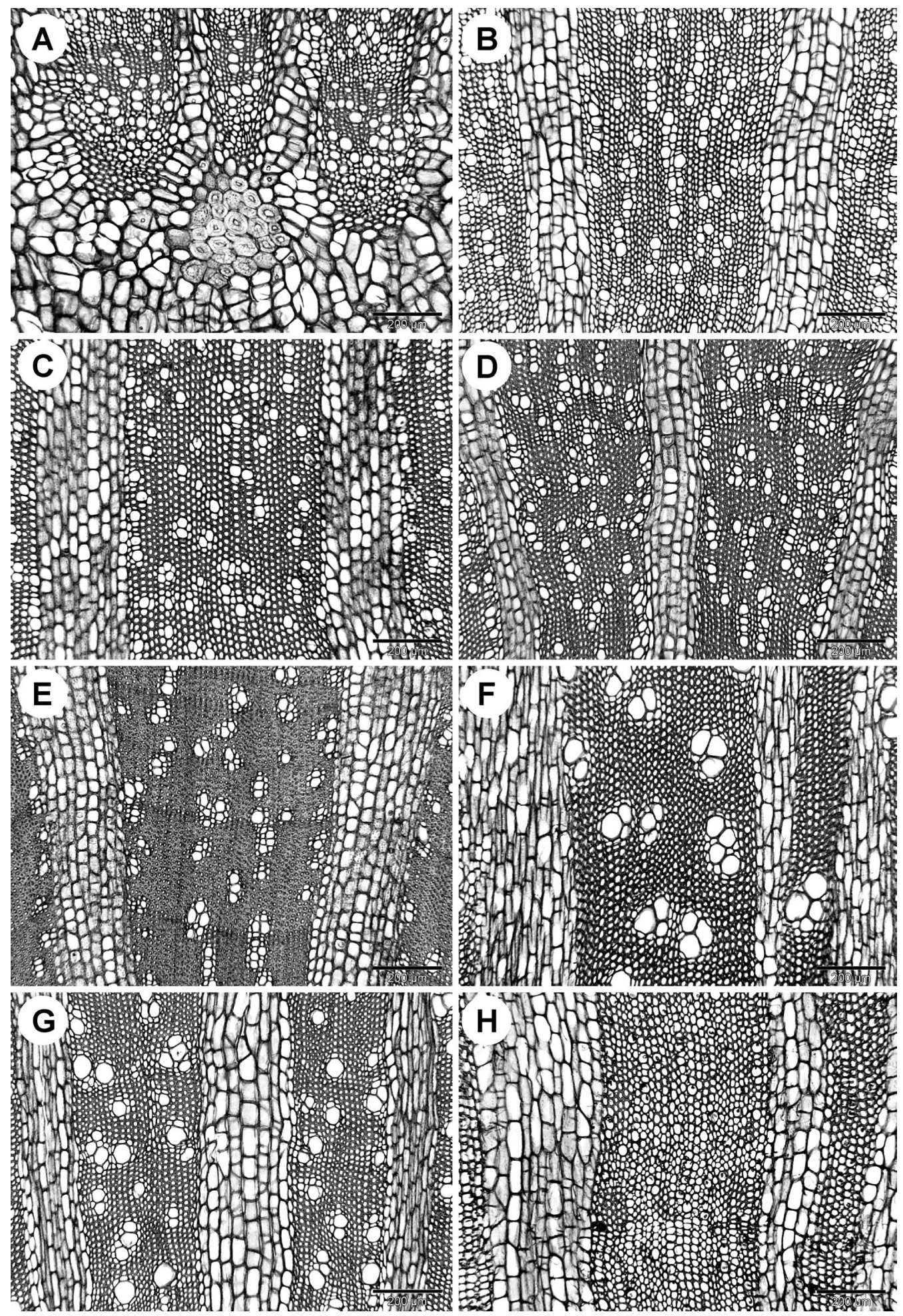

FIG. 7. Transverse sections of Theophrastaceae showing vessel arangement, paratracheal parenchyma and wide multiseriate rays. A. Clavija procera, pith with a group of sclereids, primary xylem and first formed secondary xylem. B. C. nutans, vessels solitary or in short radial multiples, very thin-walled fibers. C. C. reflexiflora, vessels solitary or in short radial multiples, very thinwalled fibers. D. Deherainia smaragdina, vessels solitary, in radial or tangential multiples, or exceptionally in clusters. E. Jacquinia berterii, vessels in clusters, thick-walled fibers. F. Bonellia frutescens, vessels in clusters, thick-walled fibers. G. B. umbellata, vessels solitary, in short radial multiples or in clusters. H. Theophrasta americana, very narrow vessels solitary or in short radial multiples. 
radial multiples (Clavija (Figs. 7A-C) and Theophrasta (Fig. $7 \mathrm{H})$ ), while vessel clustering is observed in Deherainia (Fig. 7D) and especially in Jacquinia (Fig. 7E) and Bonellia (Figs. 7F, G); vessel outline angular. Vessel perforation plates exclusively simple (Fig. 8A). Intervessel pits alternate (Fig. $8 \mathrm{~B}$ ), 3-5 $\mu \mathrm{m}$ in size, non-vestured. Vessel-ray pits similar to intervessel pitting in shape and size, sometimes unilaterally compound in Bonellia and Jacquinia. Helical sculpturing absent. Tangential diameter of vessels (12-)20-60(-80) $\mu \mathrm{m}$, (13)30-120(-154) vessels per $\mathrm{mm}^{2}$, vessel elements (120)170-440(-620) $\mu \mathrm{m}$ long. Tracheids absent. Fibers septate in Clavija (Fig. 9A) and Theophrasta, but non-septate in Deherainia, Jacquinia (few septate fibers in J. arborea), and Bonellia p.p. (septate in B. frutescens), thinto thick-walled, (175-)250-790(-920) $\mu \mathrm{m}$ long, with simple to indistinctly bordered pits concentrated in radial walls, pit borders 2-3(-4) $\mu \mathrm{m}$ in diameter, slit-like apertures sometimes elongated. Axial parenchyma scanty paratracheal with a tendency to vasicentric parenchyma in Bonellia and Jacquinia, 2-4 cells per parenchyma strand. Rays exclusively multiseriate, often 610-seriate (Figs. 8C-E, 8H), up to more than 15 cells wide in many species of Jacquinia (Figs. 8F, G) and Bonellia, (400-)1770-4480(-12000) $\mu \mathrm{m}$ (and even more) high, $0(-2-) 4$ rays per $\mathrm{mm}$, consisting of mainly procumbent body ray cells (Bonellia, Jacquinia (Fig. 9D), and Theophrasta) or procumbent and square body ray cells (Clavija (Fig. 9B) and Deherainia (Fig. 9C)), and 12 rows of square to upright marginal ray cells; multiseriate rays often dissected (Figs. $8 \mathrm{~F}-\mathrm{H}$ ), sheath cells sometimes present (Figs. 8C, F, H). Groups of sclereids in rays concentrated near the end of a growth ring in Deherainia smaragdina (Fig. 9C). Breakdown areas in rays absent. Gummy deposits in ray cells. Solitary prismatic crystals, navicular crystals and styloids present in procumbent and square ray cells of Jacquinia (Fig. 9G), solitary prismatic calcium oxalate crystals in procumbent and square ray cells of Bonellia frutescens (MADw 35912; Uw 35592), and spherical clusters of needle-shaped calcium oxalate crystals frequently observed in non-chambered procumbent ray cells of Theophrasta (Fig. 9H), and less common in Clavija longifolia, C. umbrosa, and C. weberbaueri (MADw 35911). Silica bodies mostly present in non-chambered procumbent to square ray cells of Clavija (Fig. 9E), Bonellia frutescens (Fig. 9F), B. macrocarpa, and B. shaferi. Pith including groups of sclereids (Fig. 7A); druses present in the pith of Jacquinia berterii, silica bodies in Clavija.

\section{DISCUSSION}

Our observations agree with most of the earlier wood anatomical studies, although some differences are notable. Examples of features that could not be confirmed here are the short tangential vessel multiples and very wide rays in Aegiceras, non-septate fibers in
Clavija, uniseriate rays in Cybianthus, very small multiseriate rays in Deherainia, and druses in rays of Maesa, and silica bodies in Myrsinaceae (Metcalfe and Chalk 1950; Welle 1976; Suzuki and Noshiro 1988). In addition, our scarce observations of scalariform perforations and helical thickenings in the wood of Myrsinaceae are most likely caused by our limited sampling in montane regions. Additional scalariform perforations in this family were recorded in largely montane species of Ardisia, Myrsine, and Cybianthus (Moll and Janssonius 1926; Metcalfe and Chalk 1950; Versteegh 1968), and helical thickenings were observed in Myrsine and Rapanea by Meylan and Butterfield (1978a, b).

Wood Anatomical Diversity of Primuloids within Ericales. The wood structure of primuloid families is rather homogeneous and can be characterized by a set of anatomical features, i.e. radial multiples of vessels in combination with solitary vessels, vessels with simple perforation plates and alternate vessel pitting, libriform fibers which are usually septate, scanty to vasicentric paratracheal parenchyma, and heterocellular rays (Figs. 1-9). Nevertheless, the secondary xylem can be used to define the three woody primuloid families primarily based on the ray structure, the occurrence of calcium oxalate crystals and silica bodies, and the presence of breakdown areas in rays (Figs. 10-12; Table 2). Within Ericales, the overall wood structure of primuloids can be compared with the non-related Marcgraviaceae, Tetrameristaceae, and Pellicieraceae, although these three families could clearly be distinguished from primuloids by the occurrence of apotracheal and paratracheal axial parenchyma, raphides in ray cells, and the abundance of uniseriate rays. Baas et al. (2000) did not emphasize similarities between Marcgraviaceae and primuloids in their wood anatomical comparison of Ericales. Instead, they considered the wood structure of Marcgraviaceae to be more or less primitive, linking it with other ericalean families such as Actinidiaceae, Cyrillaceae and Ericaceae. However, this is contradicted by our ongoing studies (F. Lens, pers. obs.).

According to Geuten et al. (2004), the sister group of the primuloid clade consists of Pentaphylacaceae sensu APG II (including Sladenia, Ficalhoa, and the former Ternstroemiaceae). From a wood anatomical point of view, this is surprising because Pentaphylacaceae are totally different in having solitary vessels, long vessel elements with exclusively scalariform perforations containing many bars, opposite to scalariform vessel pitting, fibers with distinctly bordered pits, diffuse apotracheal parenchyma, and co-occurrence of uniseriate and relatively low multiseriate rays (BarettaKuipers 1976; Carlquist 1984; Liang and Baas 1990). The genus Sladenia is somewhat aberrant in Pentaphylacaceae due to the occurrence of vessels in radial multiples and the tendency to alternate intervessel pitting, 

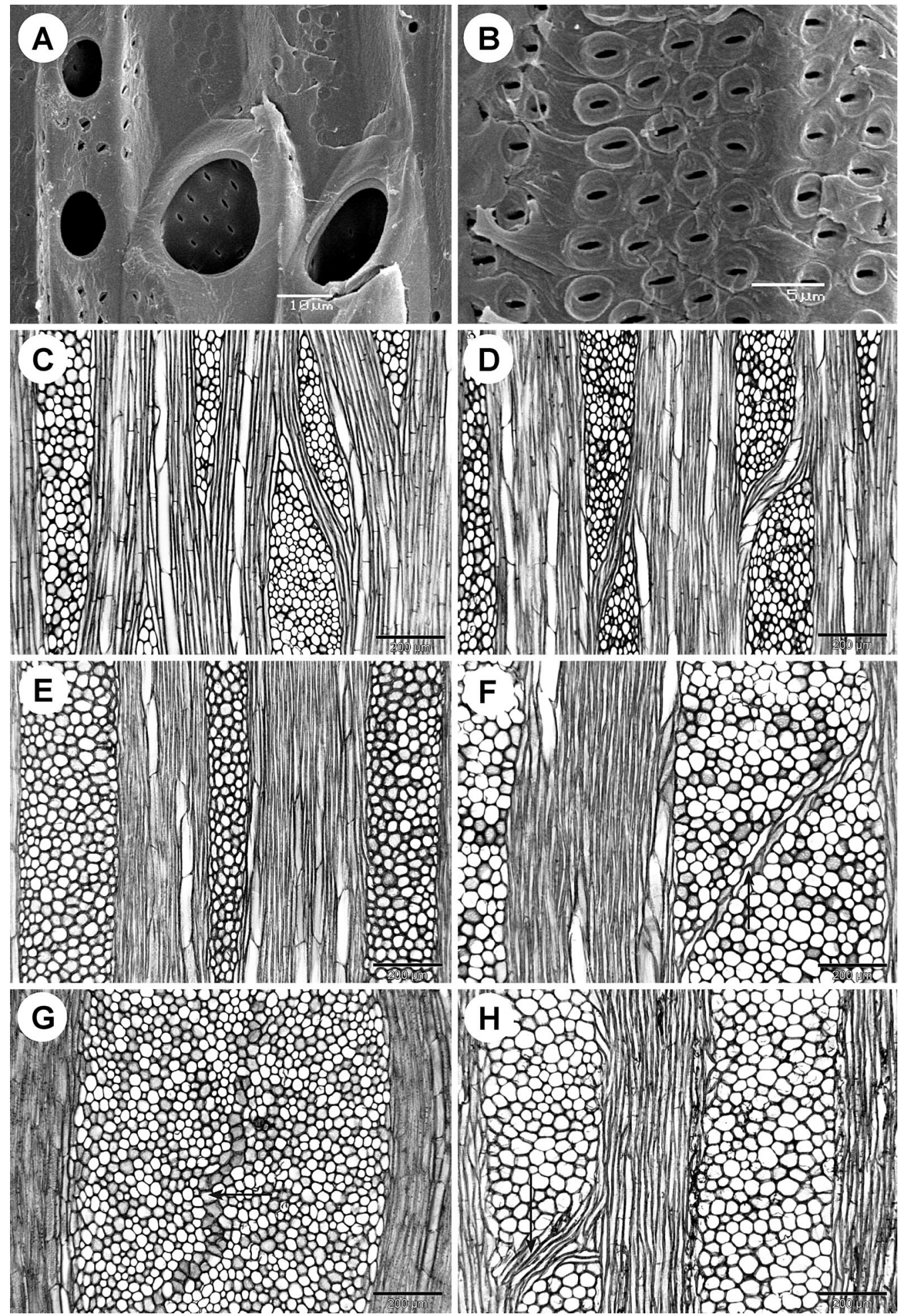

FIG. 8. Wood anatomical variation in Theophrastaceae showing vessel perforations, vessel pitting and rays. A. Clavija procera, RLS, simple vessel perforations. B. Deherainia smaragdina, RLS, alternate vessel pitting (outer pit apertures). C. C. nutans, TLS, wide multiseriate rays. D. C. procera, TLS, wide multiseriate rays. E. Deherainia smaragdina, TLS, wide multiseriate rays. F. Jacquinia arborea, TLS, detail of multiseriate ray dissection (arrow). G. J. keyensis, TLS, detail of multiseriate ray dissection (arrow). H. Theophrasta americana, TLS, detail of multiseriate ray dissection (arrow). 

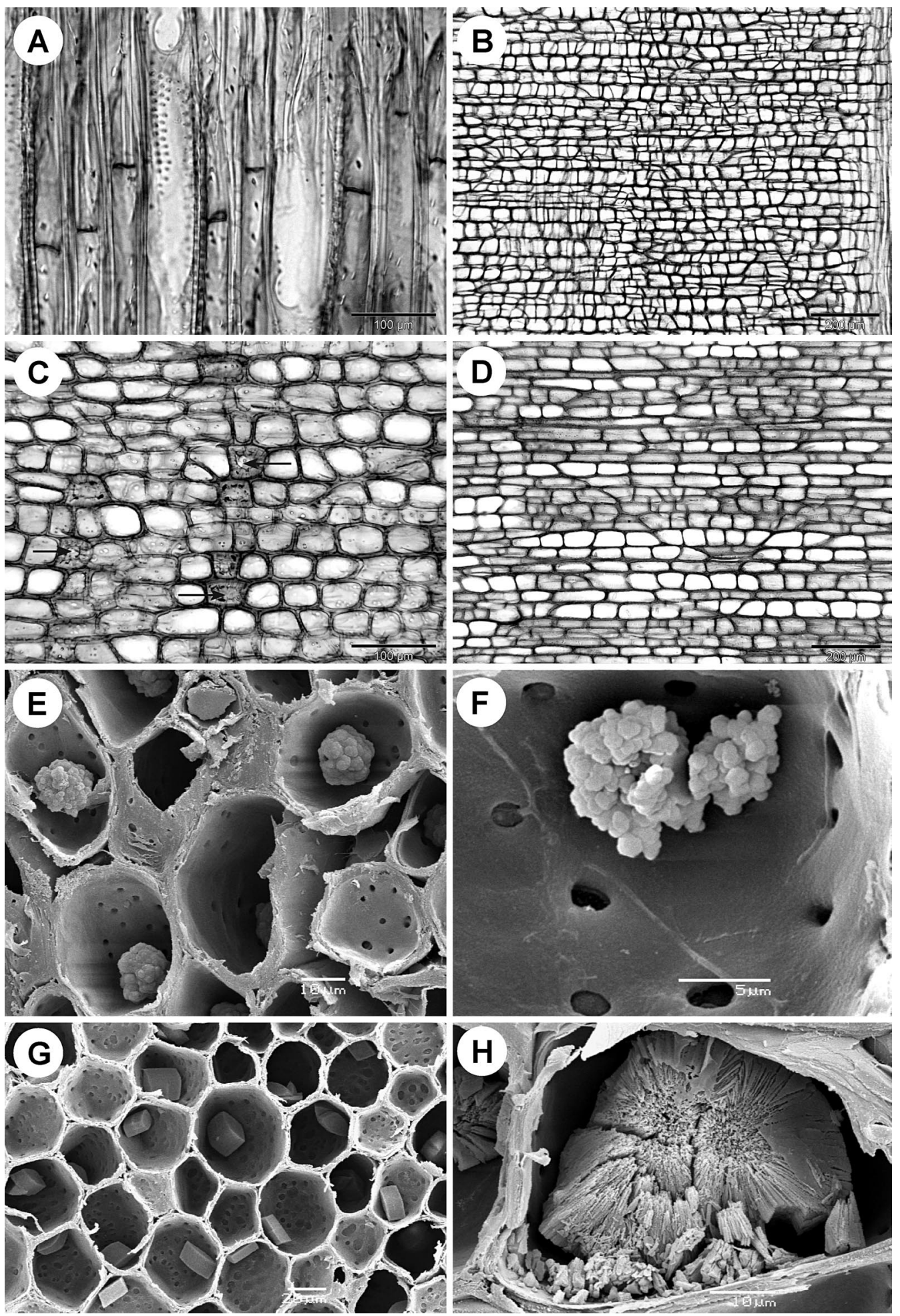

FIG. 9. Wood anatomical variation in Theophrastaceae showing fibers, rays, and mineral inclusions. A. Clavija lancifolia subsp. lancifolia, RLS, septate libriform fibers. B. C. nutans, RLS, multiseriate ray with square and procumbent body ray cells. C. RLS, Deherainia smaragdina, multiseriate ray including sclereids (arrows). D. Jacquinia arborea, RLS, multiseriate ray containing mainly procumbent body ray cells. E. C. lancifolia (Tw), TLS, silica bodies in ray cells. F. Bonellia frutescens, RLS, silica bodies in ray cells. G. TLS, J. armillaris, navicular, rectangular and prismatic crystals in ray cells. H. Theophrasta americana, RLS, spherical cluster of needle-shaped crystals in a ray cell. 
178

SYSTEMATIC BOTANY

[Volume 30
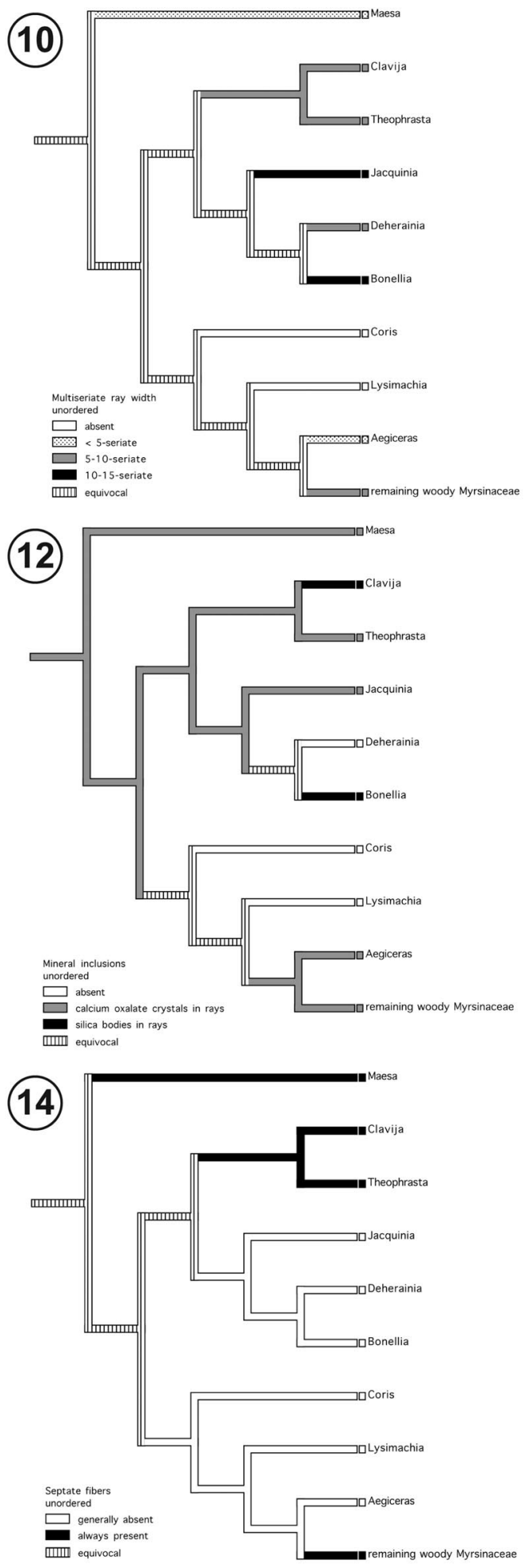
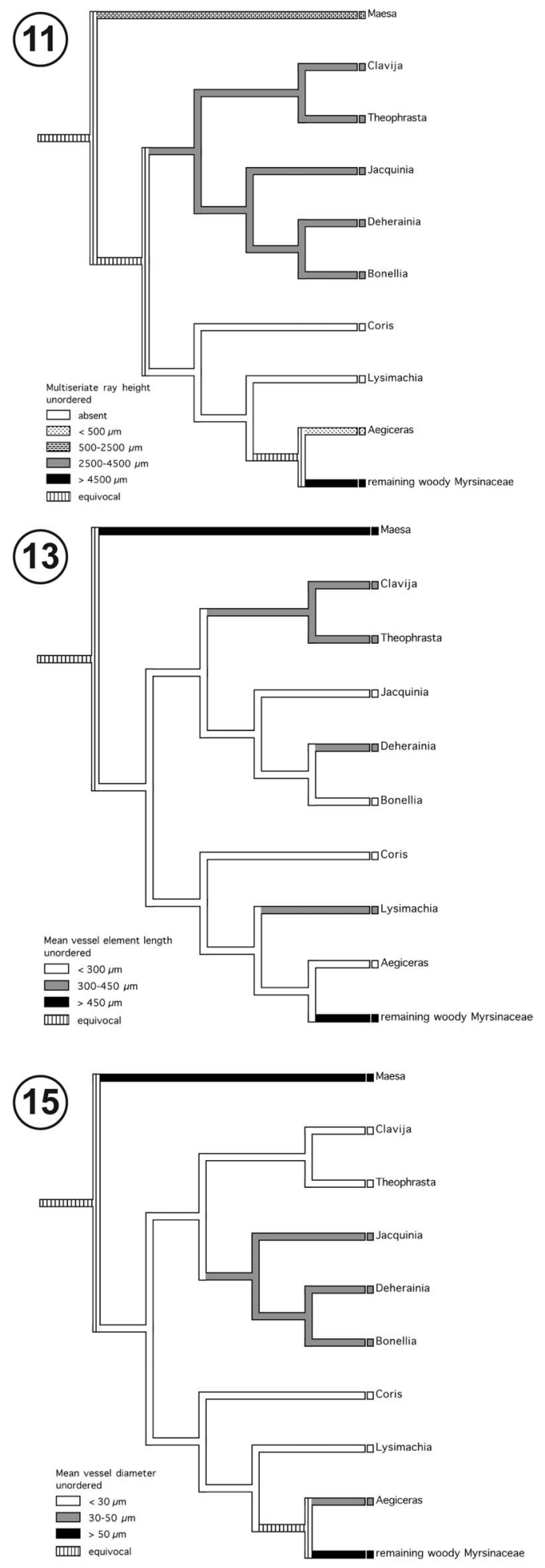

FIGs. 10-15. Simplified trees based on the molecular studies of Källersjö et al. (2000) and Källersjö and Ståhl (2003), showing the distribution of characters in woody primuloids. 10. Distribution of multiseriate ray width. 11. Distribution of multiseriate ray height. 12. Distribution of mineral inclusions. 13. Distribution of vessel element length. 14. Distribution of septate fibers. 15. Distribution of vessel diameter. 
TABLE 2. Wood anatomical comparison of the primuloid families. Only specimens with mature wood are included. *Within Myrsinaceae, the genera Coris and Lysimachia are not included because of secondary woodiness. BA = Breakdown areas in rays, HMR = Mean height of multiseriate rays $(\mu \mathrm{m}), \mathrm{LFL}=$ Mean length of libriform fibers $(\mu \mathrm{m}), \mathrm{MW}=$ Mean width of multiseriate rays (no. cells), PC $=$ Prismatic crystals, SB $=$ Silica bodies, $S F=$ Fibers usually septate, $\mathrm{SP}=$ Scalariform vessel perforations, UC $=$ Upright body ray cells, $\mathrm{UR}=$ Uniseriate rays, VEL $=$ Mean length of vessel elements $(\mu \mathrm{m}) ;+=$ present,$-=$ absent, $\pm=$ sometimes present.

\begin{tabular}{|c|c|c|c|c|c|c|c|c|c|c|c|}
\hline Family & SP & VEL & LFL & SF & UR & MW & HMR & $\mathrm{UC}$ & BA & PC & SB \\
\hline Maesaceae & \pm & $460-850$ & $980-1270$ & + & + & $2-5$ & 560-2590 & \pm & - & \pm & - \\
\hline Myrsinaceae* & \pm & $220-850$ & $440-1220$ & + & \pm & $5-10$ & 340-8250 & + & + & + & - \\
\hline Theophrastaceae & - & $170-440$ & $250-790$ & \pm & - & $5-15$ & $1770-4480$ & - & - & \pm & \pm \\
\hline
\end{tabular}

two features that are characteristic of the primuloid clade (Liang and Baas 1990). Therefore, this genus could represent a link between the enlarged Pentaphylacaceae and primuloids, but the position of Sladenia within Pentaphylacaceae remains uncertain.

Maesaceae. Typical of Maesaceae is the occurrence of uniseriate as well as multiseriate rays (Figs. 1E-F), although this combination is also present in Aegiceras (Fig. 4A) and rarely in Grammadenia (Fig. 4B) (Moll and Janssonius 1926). Because of the high percentage of uniseriate rays in Maesa, vessels are nearly always adjacent to rays, a condition which is unique within the primuloid clade (Moll and Janssonius 1926). In addition, Maesaceae show relatively long vessel elements and fibers (460-850 $\mu \mathrm{m}$ and $820-1270 \mu \mathrm{m}$, respectively), low multiseriate rays $(470-2590 \mu \mathrm{m})$, and prismatic crystals are very few to absent (Figs. 1, 11-13; Table 2). The basal position of Maesaceae within primuloids might be supported by the secondary xylem. Indeed, based on the current sister relationship with Pentaphylacaceae s.l., ancestral wood features in Maesaceae are long vessel elements (sometimes with scalariform perforations) and fibers, and a co-occurrence of uniseriate and multiseriate rays.

Myrsinaceae. This family is defined by libriform fibers showing a dense pitting in both radial and tangential walls, and by multiseriate rays that are often very high (usually more than $4500 \mu \mathrm{m}$, Fig. 11), usually consisting of procumbent, square and upright body ray cells with solitary calcium oxalate crystals (Figs. 5G-H), but always without silica bodies (Fig. 12). Furthermore, the presence of breakdown areas in rays (Figs. 3-5) is a typical feature in the wood of Myrsinaceae, although it is not observed in Coris, Embelia, Geissanthus, Grammadenia, Heberdenia, Lysimachia, and Oncostemum. According to Metcalfe and Chalk (1950), these structures also occur in the leaves (see also Große 1908), pith, and cortex of additional taxa, for instance Embelia, Grammadenia, Heberdenia, and Maesa. Until further research is carried out on the development of these cavities, discussion of their possible homology is too preliminary (Otegui et al. 1997). Breakdown areas in rays are a specialized structure that is not found in other ericalean families. Therefore, it is reasonable to believe that breakdown ray areas repre- sent a synapomorphic feature in Myrsinaceae. The socalled breakdown areas in the rays of Piper (Ilic 1987) are undoubtedly different in origin.

Generic boundaries within woody Myrsinaceae remain a matter of dispute (Coode 1976; Pipoly 1987; Anderberg and Ståhl 1995; Ricketson and Pipoly 1997; Ståhl and Anderberg 2004b). It is impossible to distinguish the genera from each other by their wood anatomy, except for Aegiceras, Coris, and Lysimachia (see below). The only suprageneric group that could be supported is Cybianthus (including Conomorpha and Weigeltia) and Grammadenia, which is placed within Cybianthus by Pipoly (1987). These taxa exhibit relatively low multiseriate rays (often between 1000 and $5000 \mu \mathrm{m}$, except for Cybianthus comperuvianus), a feature that is rare in other Myrsinaceae.

Aegiceras can easily be distinguished from other Myrsinaceae by the presence of relatively narrow vessels, a relatively high vessel density, short vessel elements and fibers (which are both storied), non-septate fibers, a combination of low uni- and multiseriate rays (about 100-400 $\mu \mathrm{m}$ ), and multiseriate rays with exclusively procumbent body ray cells and without sheath cells (Figs. 11, 13-15). On the other hand, the characteristic breakdown areas in rays are clearly present (Figs. 3A, 4A, 5E) (Moll and Janssonius 1926; Panshin 1932; Metcalfe and Chalk 1950). At least some of these differences are related to the mangrove habit of Aegiceras. Tomlinson (1986) noted that the wood of mangrove species typically has a high number of narrow vessels, which are less vulnerable to cavitation, causing a safer sap stream. Furthermore, short vessel elements could also contribute to the safety of the sap stream in mangroves, which experience strongly negative pressures in their vessels due to the saline, physiologically dry, environment (Carlquist 1977). However, Panshin (1932) and van Vliet (1976) mentioned that the vessel element length of mangrove inhabitants does not differ considerably from the inland representatives. There are also other morphological features in Aegiceras that are atypical of Myrsinaceae, such as the presence of versatile anthers, viviparous fruits with exalbuminous seeds, and unitegmic ovules (Ståhl and Anderberg 2004b). According to some authors, it seems highly unlikely that all these differences can be ex- 
plained by the mangrove habit, supporting the idea to elevate Aegiceras to family level (de Candolle 1844; Dahlgren 1989). However, molecular data show that Aegiceras falls within a well supported clade including all other woody taxa of Myrsinaceae studied (Källersjö et al. 2000).

Theophrastaceae. The genera Bonellia and Clavija of Theophrastaceae can be distinguished from Myrsinaceae, Maesaceae, and other Theophrastaceae genera studied by the presence of silica bodies (Figs. 9E, F, 12; ter Welle 1976). Spherical clusters of needle-shaped calcium oxalate crystals are only observed in Clavija and Theophrasta (Fig. 9H). Jacquinia shows solitary calcium oxalate crystals (Fig. 9G), which are typical of Myrsinaceae, while Deherainia lacks mineral inclusions (Fig. 12). Generally, the wood of Theophrastaceae is characterized by very short vessel elements and fibers (on average $170-440 \mu \mathrm{m}$ and $250-790 \mu \mathrm{m}$, respectively), values that are also found within primuloids in Aegiceras, Coris, and Lysimachia (Fig. 13). In addition, the family often exhibits wide multiseriate rays with few sheath cells (sometimes more than 20 cells wide; Fig. $8 \mathrm{G})$, although 20-seriate rays or wider are also observed in some Myrsinaceae taxa, such as Embelia, Geissanthus, and Parathesis (see also Metcalfe and Chalk 1950).

Within Theophrastaceae, there are two major clades: a pachycaulous group containing Clavija, Neomezia, and Theophrasta, and a richly branching group of Bonellia, Deherainia, Jacquinia, and Votschia (de Candolle 1844; Ståhl 1991, 2004b; Källersjö and Ståhl 2003). The species studied of the pachycaulous group differ from the richly branched clade in vessel diameter (usually $<30$ and 30-50 $\mu \mathrm{m}$, respectively, Fig. 15), vessel density (on average often $60-80$ and 30-60 vessels per $\mathrm{mm}^{2}$, respectively), length of vessel elements (usually 300-450 and $<300 \mu \mathrm{m}$, respectively, Fig. 13), fiber length (often 500-700 and 400-500 $\mu \mathrm{m}$, respectively), and the width of multiseriate rays (less than 15-seriate vs. more than 10-seriate, Fig. 10). Furthermore, some features are typical of the pachycaulous clade, such as septate fibers (Fig. 14) and spherical clusters of calcium oxalate crystals (Theophrasta americana and some Clavija species), while the richly branched clade is characterized by pronounced vessel clustering.

Most pachycaulous Clavija and Theophrasta species are unbranched or sparsely branched shrubs or treelets with a rather thin main stem, mostly reaching only a few meters in height (Ståhl 1987, 1991). Their habit is clearly different from the thick pachycaulous bottle trees, which are anatomically characterized by a higher quantity of parenchyma tissue, wider vessels, and a lower vessel density (Olson and Carlquist 2001; Olson 2003). The narrow vessels of the pachycaulous clade can functionally be interpreted by the presence of a single bunch of terminal leaves, which require a small- er number of wide vessels than stems supplying a fully branched crown (Fig. 15). Apparently, the influence of the single-stemmed or sparsely branched habit on vessel diameter exceeds the ecological impact in Clavija. Indeed, most Clavija species grow in wet evergreen forests (Ståhl 2004), a habitat in which plants characteristically show wide vessels, low vessel densities and long vessel elements. On the other hand, ecological influences are much clearer in the wood of Bonellia and Jacquinia, which typically occur in seasonally dry thorn scrub vegetation (Ståhl 2004). The secondary xylem of the two genera shows several features that are in agreement with other taxa growing in similar seasonally dry vegetation types, such as the presence of very short vessels with simple perforations, relatively narrow vessel diameters, and an increase of vessel multiples (Carlquist and Hoekman 1985).

The presence of silica grains in Bonellia and the absence of silica in Jacquinia supports the decision to divide Jacquinia s.l. into two genera (Ståhl and Källersjö 2004, Fig. 12), but in other respects the wood structure of Jacquinia is almost identical to Bonellia. The difference in mineral inclusions and corolla color between both genera might possibly reflect different metabolic pathways.

Relationship Between Myrsinaceae and Theophrastaceae. Within woody Ericales, Myrsinaceae and Theophrastaceae are the only two families that lack uniseriate rays, although Aegiceras represents an interesting exception. Since the absence of uniseriate rays in Ericales is most likely a derived condition, and because these two families are without doubt closely related, uniseriate rays probably have been lost in the woody common ancestor of Myrsinaceae, Theophrastaceae, and the herbaceous Primulaceae, indicating a plausible synapomorphy for Myrsinaceae and Theophrastaceae. Besides the wood features that are typical of the primuloid clade, other characters linking both families are the presence of vessel clusters and relatively wide multiseriate rays (more than 10-seriate) in some Myrsinaceae species and in the majority of Theophrastaceae species studied. Furthermore, ray dissection is common (Otegui 1994). The wide rays and wide vessels in Embelia are probably correlated with the scandent habit.

Secondary Woodiness. Coris and Lysimachia show an aberrant wood structure compared to other woody Myrsinaceae. Notable differences are the short and narrow vessel elements, short and non-septate fibers, and the absence of rays (Aymard 1968). Furthermore, the length of vessel elements decreases significantly from the centre of the stem towards the periphery, a phenomenon often observed in paedomorphic woods (i.e. woods that remain permanently juvenile; Carlquist 1962). These anomalies are most likely caused by secondary woodiness, a term that is used for woody 
plants (often asterids) that evolved from herbaceous ancestors (Carlquist 1992). As a result, wood anatomy cannot provide evidence for the systematic position of these two genera (Carlquist 1962). The possible presence of secondary woodiness in Coris and Lysimachia is supported by molecular analyses of Källersjö et al. (2000) and Anderberg et al. (2001), since these genera are closely related to herbaceous genera. Woody Myrsinaceae on the other hand (except for Coris and Lysimachia), form a monophyletic group and are derived within a larger clade including the rest of Myrsinaceae and Primulaceae. However, the hypothesis of Anderberg et al. (2001) that the common ancestor of the clade formed by Samolaceae-Theophrastaceae-MyrsinaceaePrimulaceae is herbaceous seems unlikely because all woody primuloids investigated (except for Coris and Lysimachia) do not show clear signs of secondary woodiness.

ACKNOWLEDGEMENTS. The director of the National Botanic Garden of Belgium (BR), the curators of the wood collection of Kew (Kw), Madison (MADw, SJRw), Tervuren (Tw), and Utrecht (Uw), Dr. B. Ståhl, and Dr. A.A. Anderberg are greatly acknowledged for their supply of wood samples. We thank Prof. P. Baas (Nationaal Herbarium Nederland) for his valuable comments on this manuscript, Anja Vandeperre (K.U.Leuven) for technical assistance, and Marcel Verhaegen (National Botanic Garden of Belgium) for the preparation of SEM-images. This work has financially been supported by research grants from the K.U.Leuven (OT/01/25), the Fund for Scientific Research-Flanders (Belgium) (G.104.01, 1.5.069.02, 1.5.061.03). Steven Jansen is a postdoctoral fellow of the Fund for Scientific Research-Flanders (Belgium) (F.W.O.--Vlaanderen).

\section{LiTERATURE CITED}

ANDERBERG, A. A. and B. STÅHL. 1995. Phylogenetic relationships in the Primulales inferred from $r b c L$ sequence data. Plant Systematics and Evolution 211: 93-102.

_- C.-I. Peng, I. Trift, and M. KÄLlersjö. 2001. The Stimpsonia problem; evidence from DNA sequences of plastid genes atpB, ndhF and rbcL. Botanischer Jahrbücher für Systematik 123: 369-376.

_ C. RYDIN, and M. KÄLLERSJÖ. 2002. Phylogenetic relationships in the order Ericales s.l.: analyses of molecular data from five genes from the plastid and mitochondrial genomes. American Journal of Botany 89: 677-687.

— B. STÅHL, and M. KÄLLERSJÖ. 1998. Phylogenetic relationships in the Primulales inferred from $r b c L$ sequence data. Plant Systematics and Evolution 211: 93-102.

—_ B. STÅHL, and M. KÄLLERSJÖ. 2000. Maesaceae, a new primuloid family in the order Ericales s.l. Taxon 49: 183-187.

APG II. 2003. An update of the Angiosperm Phylogeny Group classification for the orders and families of flowering plants: APG II. Botanical Journal of the Linnaean Society 141: 399-436.

AYMARD, M. 1968. Le xylème secondaire chez Lysimachia punctata L. Bulletin de la Société Botanique de France 115: 187-196.

BAAS, P., E. WHEELER, and M. CHASE. 2000. Dicotyledonous wood anatomy and the APG system of angiosperm classification. Botanical Journal of the Linnaean Society 134: 3-17.

BARETTA-KUIPERS, T. 1976. Comparative wood anatomy of Bonnetiaceae, Theaceae and Guttiferae. Pp. 76-101 in Wood structure in biological and technological research, Vol. III, eds. P. Baas,
A. J. Bolton, and D. M. Catling. Leiden: Leiden University Press.

Bremer, B., K. Bremer, N. Heidari, P. Erixon, R. G. Olmstead, A. A. ANDERbERG, M. KÄLlersjö, and E. BARKHORDARIAN. 2002. Phylogenetics of asterids based on 3 coding and 3 noncoding chloroplast DNA markers and the utility of non-coding DNA at higher taxonomic levels. Molecular Phylogenetics and Evolution 24: 274-301.

CARIS, P. and E. SMETS. 2004. A floral ontogenetic study on the sister group relationship between the genus Samolus (Primulaceae) and the Theophrastaceae. American Journal of Botany 91: 627-643.

- L. P. Ronse Decraene, E. SMets, and D. Clinckemaillie. 2000. Floral development of three Maesa species, with special emphasis on the position of the genus within Primulales. Annals of Botany 86: 87-97.

CARLQuist, S. 1962. A theory of paedomorphosis in dicotyledonous woods. Phytomorphology 12: 30-45.

. 1977. Wood anatomy of Onagraceae: additional species and concepts. Annals of the Missouri Botanical Garden 64: 627637.

. 1984. Wood anatomy and relationships of Pentaphylacaceae: significance of vessel features. Phytomorphology 34: 8490.

. 1992. Wood anatomy of sympetalous dicotyledon families: a summary with comments on systematic relationships and evolution of the woody habit. Annals of the Missouri Botanical Garden 79: 303-332.

- 2001. Comparative wood anatomy. Systematic, ecological, and evolutionary aspects of dicotyledon wood, 2nd ed., Berlin: Springer.

- and D. A. Hoekman. 1985. Ecological wood anatomy of the woody southern Californian flora. International Association of Wood Anatomists Bulletin, new series 6: 319-347.

Coode, M. J. E. 1976. Notes on Pittosporaceae and Myrsinaceae of the Mascarenes. Kew Bulletin 31: 221-225.

Cronguist, A. 1988. The evolution and classification of flowering plants, $2^{\text {nd }}$ ed. Bronx: New York Botanical Garden.

DAHLGREN, G. 1989. The last Dahlgrenogram. System of classification of the dicotyledons. Pp. 249-260 in The Davis and Hedge Festschrift, ed. K. Tan. Edinburgh: Edinburgh University Press.

DE CANDOlle, A. P. 1844. Prodromus systematis naturalis regni vegetabilis, 8th ed. Paris: Sumptibus Sociorum Treuttel et Würtz.

DétienNe, P., P. JACQUet, and A. MARIAUX. 1982. Manuel d'identification des bois tropicaux. 3. Guyane française. Nogentsur-Marne: Centre Technique Forestier Tropical.

Geuten, K., E. SMets, P. Schols, Y.-M. YuAN, S. JANSSENS, P. KÜPFER, and N. PYCK. 2004. Conflicting phylogenies of balsaminoid families and the polytomy in Ericales: combining data in a Bayesian framework. Molecular Phylogenetics and Evolution 31: 711-729.

GROßE, A. 1908. Anatomisch-systematische Untersuchingen der Myrsinaceen. Botanische Jahrbücher 41,Beiblatt 96: 1-46.

IAWA COMMITTEE. 1989. IAWA list of microscopic features for hardwood identification. International Association of Wood Anatomists Bulletin, new series 10: 219-332.

ILIC, J. 1987. The CSIRO key for hardwood identification. Leiden: E. J. Brill.

Jansen, S., P. Kitin, H. De Pauw, M. IdRIS, H. BeECKMAN, and E. SMETS. 1998. Preparation of wood specimens for transmitted light microscopy and scanning electron microscopy. Belgian Journal of Botany 131: 41-49.

KÄLLERSJÖ, M. and B. STÅHL. 2003. Phylogeny of Theophrastaceae (Ericales, s. lat.). International Journal of Plant Sciences 164: 579591.

, G. Bergqvist, and A. A. Anderberg. 2000. Generic re- 
alignment in primuloid families of the Ericales s.l.: a phylogenetic analysis based on DNA sequences from three chloroplast genes and morphology. American Journal of Botany 87: 1325-1341.

KUBITZKI, K. 2004. Families and genera of flowering plants. Vol. VI. Berlin: Springer-Verlag.

LIANG, D. and P. BAAS. 1990. Wood anatomy of trees and shrubs from China II. Theaceae. International Association of Wood Anatomists Bulletin, new series 11: 337-378.

- and P. BAAS. 1991. The wood anatomy of the Theaceae. International Association of Wood Anatomists Bulletin, new series 12: 333-353.

Maddison, D. R. and W. P. MAdDison. 2002. MacClade 4.04. Sunderland: Sinauer Associates.

Metcalfe, C. R. and L. ChalK. 1950. Anatomy of the dicotyledons, Vol. II. Oxford: Clarendon Press.

MeYLAN, B. A. and B. G. BUTTERfieLD. 1978a. Occurrence of helical thickenings in the vessels of New Zealand woods. New Phytologist 81: 139-146.

and B. G. ButTERFIELD. 1978b. The structure of New Zealand woods. Wellington: New Zealand Department of Scientific and Industrial Research.

Mez, C. 1902. Myrsinaceae. Pp. 1-437 in Das Pflanzenreich, Vol. IX, ed. A. Engler. Leipzig: Engelmann.

1903. Theophrastaceae. Pp. 1-48 in Das Pflanzenreich, Vol. $\mathrm{XV}$, ed. A. Engler. Leipzig: Engelmann.

Moll, J. W. and H. H. JANssonius. 1926. Mikrographie des Holzes der auf Java vorkommendes Baumarten, Vol. IV. Leiden: E. J. Brill.

Ogata, K. and A. Kalat. 1997. Wood anatomy of some trees, shrubs and climbers in Brunei Darussalam. After-care Programme, Brunei Forestry Research Project Special Publication No. 3. Brunei Darussalam: Japan International Cooperation Agency (JICA) and Forestry Department, Ministry of Industry and Primary Resources.

Olson, M. E. 2003. Stem and leaf anatomy of the arboreAscent Cucurbitaceae Dendrosicyos socotrana with comments on the evolution of pachycauls from lianas. Plant Systematics and Evolution 239: 199-214.

lations with life form diversity, ecology, and systematics in Moringa (Moringaceae). Botanical Journal of the Linnaean Society 135: 315-348.

OTEGUI, M. S. 1994. Occurrence of perforated ray cells and ray splitting in Rapanea laetivirens and R. lorentziana (Myrsinaceae). International Association of Wood Anatomists Journal 15: 257-263.

- M. L. Gaspar, S. Maldonado, E. L. Varetti, and R. PolLERO. 1997. Studies on tissues associated to hydrobenzoquinone secretion in Myrsine laetivirens (Myrsinaceae). Nordic Journal of Botany 18: 447-459.

PANSHIN, A. J. 1932. An anatomical study of the woods of the Philippine mangrove swamps. Philippine Journal of Science 48: 143-207.

PAX, F. 1889. Myrsinaceae. Pp. 84-97 in Die natürlichen Pflanzenfamilien, Vol. IV, eds. A. Engler and K. Prantl. Leipzig: Engelmann.

PIPOLY, J. J. 1987. A systematic revision of the genus Cybianthus subgenus Grammadenia (Myrsinaceae). Memoirs of the New York Botanical Garden 43: 1-76.

Ricketson, J. M. and J. J. Pipoly. 1997. Nomenclatural notes and a synopsis of the genus Myrsine (Myrsinaceae) in Mesoamerica. Sida 17: 579-589.

Sosef, M. S. M., L. T. Hong, and S. Prawirohatmodjo. 1998. Plant Resources of South-East Asia. No 5. Timber trees: lesser known timbers. Leiden: Backhuys Publishers.

STÅHL, B. 1987. The genus Theophrasta (Theophrastaceae). Foliar structures, floral biology and taxonomy. Nordic Journal of Botany 7: 529-538.
1991. A revision of Clavija (Theophrastaceae). Opera Botanica 107: 1-77.

. 2004a. Samolaceae. Pp. 387-389 in Families and genera of vascular plants, Vol. VI, ed. K. Kubitzki. Berlin: Springer-Verlag.

- 2004b. Theophrastaceae. Pp. 472-478 in Families and genera of vascular plants, Vol. VI, ed. K. Kubitzki. Berlin: SpringerVerlag.

- and A. A. Anderberg. 2004a. Maesaceae. Pp. 255-257 in Families and genera of vascular plants, Vol. VI, ed. K. Kubitzki. Berlin: Springer-Verlag.

and A. A. ANDERBERG. 2004b. Myrsinaceae. Pp. 266-281 in Families and genera of vascular plants, Vol. VI, ed. K. Kubitzki. Berlin: Springer-Verlag.

- and M. KÄLLERSJö. 2004. Reinstatement of Bonellia (Theophrastaceae). Novon 14: 115-118.

STERN, W. L. 1988. Index Xylariorum. Institutional wood collections of the world, 3rd. ed. International Association of Wood Anatomists Bulletin, new series 9: 204-252.

SUZUKI M. and S. NosHIRO. 1988. Wood structure in Himalayan Plants. Bulletin of the National Science Museum, Tokyo 31: 341379.

Tomlinson, P. B. 1986. The botany of mangroves. New York: Cambridge University Press.

VAN Vliet, G. J. C. M. 1976. Wood anatomy of Rhizophoraceae. Leiden Botanical Series 3: 20-75.

VERSTEEGH, C. 1968. An anatomical study of some woody plants in the mountain flora in the tropics (Indonesia). Acta Botanica Neerlandica 17: 151-159.

WEBbER, I. E. 1938. Intercellular cavities in the rays of dicotyledonous woods. Lilloa 3: 465-473.

WELLE, B. J. H. TER. 1976. Silica grains in woody plants of the neotropics, especially Surinam. Pp. 107-142 in Wood structure in biological and technological research, Vol. III, eds. P. Baas, A. J. Bolton, and D.M. Catling. Leiden: Leiden University Press. WiLliams, L. 1936. Woods of Northeastern Peru. Field Museum of Natural History Publications 15: 402-406.

\section{APPENDIX}

The wood samples studied are listed below with reference to the origin, collector, and the diameter of the wood sample in $\mathrm{mm}$. "Mature" means that the wood sample is derived from mature wood, although the exact diameter could not be traced. Institutional wood collections used in this study are abbreviated according to the Index Xylariorum (Stern 1988). The other institution that was used to collect wood samples is the National Botanic Garden of Belgium (BR).

Aegiceras majus Gaertn.; Australia: Narrabeen, E.F. Constable 24199 (BR), 6 mm. A. majus Gaertn.; Philippines, Philippine Bureau of Forestry 10260 (MADw 5198), mature. Afrardisia staudtii Mez; R. D. Congo, J. Louis 3647 (BR), 10 mm. Ardisia cauliflora Mart. \& Miq.; Brazil, B.A. Krukoff 5662 (Uw 20106), $55 \mathrm{~mm}$. A. copelandii Merr.; Northern Borneo, S. Herb 26792 (Tw 17538), mature. A. manglillo Cuatrec.; Colombia, J. Cuatrecasas 16304 (Tw 39542), mature. A. obovata Desv. ex J.C.Hassk.; Puerto Rico: Nanauta, R.A. Howard 16802 (BR), 7 mm. Badula barthesia A.DC.; Sri Lanka, Kramer 9441 (Uw 33647), 14 mm. Bonellia frutescens (Mill.) B.Ståhl \& Källersjö; Venezuela, L. Williams 12185 (MADw 35912; Uw 35592), 30 mm. B. frutescens (Mill.) B.Ståhl \& Källersjö; Venezuela, H. Pittier 12425 (MADw 36654), 32 mm. B. cf. macrocarpa (Cav.) B.Ståhl \& Källersjö; Mexico: Quiroga, A. Curtis s.n. (Tw 45664), mature. B. macrocarpa (Cav.) B.Ståhl \& Källersjö subsp. pungens (A.Gray) B.Ståhl \& Källersjö; Mexico: Sonora, P. Fryxell 3070 (BR), 4 mm. B. shaferi (Urb.) B.Ståhl \& Källersjö; Cuba: Camagüey, Maragaoa, R. Dechamps 12718 (Tw 51964), mature. B. stenophylla (Urb.) B.Ståhl \& Källersjö; Cuba, A.J. Fors 985 (MADw 14446), mature. B. umbellata (A.DC.) B.Ståhl \& Källersjö; Puerto Rico, G. Caminero et al. 485 (MADw 47821), $23 \mathrm{~mm}$. Clavija lancifolia Desf. subsp. lancifolia; Surinam, 
Lindeman 4463 (Tw 26168), $24 \mathrm{~mm}$. C. lancifolia Desf. subsp. chermontiana (Standl.) B.Ståhl; Guyana, M. Jansen-Jacobs et al. 1518 (Uw 33202), 16 mm. C. longifolia Ruiz \& Pav.; Peru, J. Schunke 4884 (MADw 39288), 29 mm. C. nutans (Vell.) B.Ståhl; Brazil, Lindeman et al. 1486 (Uw 13101), 11 mm. C. nutans (Vell.) B.Ståhl; Bolivia, M. Nee 40976 (MADw 46866), 16 mm. C. procera B.Ståhl; Ecuador, W. Palacios 1339 (Kw 49865), $21 \mathrm{~mm}$. C. tarapotana Mez; Peru, J. Schunke 4239 (MADw 39072), 23 mm. C. umbrosa Regel; Brazil, B.A. Krukoff 6742 (Uw 7908, MADw 34206), $40 \mathrm{~mm}$. C. weberbaueri Mez; Peru, Ellenberg 2523 (Uw 8723), $11 \mathrm{~mm}$. C. weberbaueri Mez; Brazil, B.A. Krukoff 8136 (MADw 35911), 26 mm. Coris monspeliensis L.; Spain: Almeria, P. Auquier et al. 6765 (BR), 4 mm. Ctenardisia stenobotrys (Standl.) Lundell \& Pipoly; Venezuela, M. Nee 30825 (MADw 44258), $31 \mathrm{~mm}$. Cybianthus comperuvianus Pipoly; Bolivia, B.A. Krukoff s.n. (SJRw 39748), $44 \mathrm{~mm}$. C. magniifolia (Mez) G.Agostini; Venezuela: Amazone, B. Maguire et al. 42702 (Tw 38185), $18 \mathrm{~mm}$. C. multiflorus (A.C.Sm.) G.Agostini; Brazil, B.A. Krukoff 7290 (MADw 36606), $23 \mathrm{~mm}$. C. peruvianus Miq.; origin and collector unknown (SJRw 46505), $27 \mathrm{~mm}$. C. prieurei A.DC. Guyana, Stoffers et al. 138 (Uw 30091), 24 mm. C. psychotriaefolius Rusby; Brazil: Acre, B.A. Krukoff 5753 (Tw 34513), 20 mm. Deherainia smaragdina Decne.; Mexico, collector unknown (BR 19726256), $14 \mathrm{~mm}$. Discocalyx megacarpa Merr.; Philippines, H.A. Miller and Ponape 6692 (Uw 16699), 14 mm. D. insignis Merr.; Philippines: Surigao, C.A. Wenzel 3326 (BR), $10 \mathrm{~mm}$. Embelia kilimandscharica Gilg; East Africa, Reinbek 1703 (Uw 15919), 24 mm. E. multiflora Taton; origin unknown, A. Leonard 2049 (BR), 8 mm. E. schimperi Vatke; Ethiopia, J.J.F.E. De Wilde 6157 (BR), 6 mm. E. upembensis Taton; Democratic Republic of Congo: Shaba, E. Malaisse 9393 (Tw 31827), $21 \mathrm{~mm}$. Geissanthus angustiflorus Cuatrec.; Colombia, J. Cuatrecasas 14872 (Uw 25110), 55 mm. G. quindiensis Mez; Colombia, J. Cuatrecasas 20064 (Tw 39724, MADw 17622), mature. Grammadenia lineata Benth.; Venezuela: Amazone, B. Maguire et al. 37052 (Tw 36547), $12 \mathrm{~mm}$. G. parasitica Griseb.; Dominica, W. Stern and Wasshausen 2554 (MADw 24234), $16 \mathrm{~mm}$. Heberdenia bahamensis Sprague; Spain: Madeira, collector unknown (Tw 22947), mature. Jacquinia arborea Vahl; Dominica, Chambers 2634 (Uw 2634), $32 \mathrm{~mm}$. J. arborea Vahl; Puerto Rico, M. Nee 44191 (MADw 47975), $48 \mathrm{~mm}$. J. cf. armillaris Jacq.; USA, Fairchild Tropical Garden 61493 (MADw 43800), 33 mm. J. berterii Spreng.; Guadeloupe, Rollet 1137 (Uw 29675), mature. J. berterii Spreng.; Puerto Rico, Knudsen and B. Ståhl 67, 12 mm. J. keyensis Mez; USA: Florida, W. Stern et al. 3063 (Uw 20284), 48 mm. J. keyensis Mez; USA, W. Stern 123 (MADw 16890), 40 mm. Lysimachia kalalauensis Skottsb.; USA: Hawaii, W. Stern 2998
(Tw 24160), 7 mm. L. vulgaris L.; Spain: Begonte, Lugo et al. s.n. (BR), 6 mm. Maesa indica Wall.; India: Amla, Sikkim 551 (Tw 47058), mature. M. lanceolata Forssk.; Africa, Reinbek 1598 (Uw 15537), 45 mm. M. lanceolata Forssk. var. rufescens (A.DC.) Taton; Democratic Republic of Congo: Kivu, J. Lebrun 5412 (Tw 910), mature. M. macrothyrsa Miq.; Malaysia, W. Meijer 122550 (MADw 48614), $15 \mathrm{~mm}$. M. ramentacea Wall.; Brunei, Ogata et al. 317 (MADw 48458), 15 mm. M. schweinfurthii Mez; Democratic Republic of Congo: Zemio, R. Boutique 163 (BR), 8 mm. Myrsine angustifolia (Mez) Hosaka; USA: Hawaii, W. Stern 2931 (Tw 24104), mature. M. lessertiana A.DC.; USA: Hawaii, S.H. Lamb 26 (BR), 36 mm. M. sandwicensis A.DC.; USA: Hawaii, S.H. Lamb 24 (Tw 35928), 36 mm. Oncostemum botryoides Baker; Madagascar, L.J. Dorr et al. 3584 (MADw 44414), 24 mm. O. cauliflorum H.Perrier; Madagascar: Tamatave, J.L. Dorr 3136 (Tw 44790), 19 mm. O. leprosum Mez; Madagascar, Thouvenot 133 (MADw 34230), mature. O. venulosum Baker; Madagascar, L.J. Dorr and L.C. Barnett 3193 (MADw 44367), 11 mm. Parathesis chiapensis Fernald; Mexico, D. Breedlove 9658 (MADw 23890), 40 mm. P. chrysophylla Lundell; Guatemala, C. Galluser 3 (MADw 34231), 47 mm. P. crenulata Hemsl.; Panama, G.P. Cooper 464 (MADw 34232), $28 \mathrm{~mm}$. P. cubana (A.DC.) Molinet \& B.A.Gomes; Cuba: Pinar del Rio, R. Dechamps 12458 (Tw 49932), 17 mm. P. leptopa Lundell; Mexico, D. Breedlove 9724 (MADw 23924), $48 \mathrm{~mm}$. P. rekoi Standl.; Guatemala, S.J. Record and H. Kuylen 44 (MADw 10989), $50 \mathrm{~mm}$. Rapanea australis (A.Rich.) W.R.B.Oliv.; New Zealand, A.M. Greeb 1467 (Tw 19867), mature. R. dependens (Spreng.) Mez var. petandra Cuatrec.; Colombia, J. Cuatrecasas 20138 (Tw 39726), mature. R. gracicolor Mildbr.; Africa: near Tanganyika, Reinbek 1660 (Uw 15570), 35 mm. R. guianensis (Aubl.) Kuntze; Surinam, H.P. Bottelier 2605 (BR), 18 mm. R. melanophloeos (L.) Mez; Rwanda, G. Troupin 14490 (Tw 26067), mature. R. quaternata Hassl.; Paraguay, Lindeman et al. 1496 (Uw 13111), $35 \mathrm{~mm}$. Stylogyne amplifolia Macbr.; Peru, Mathias and Taylor 5469 (Uw 27158), $38 \mathrm{~mm}$. S. amplifolia Macbr.; Peru, J. Schunke 4374 (MADw 38788), $30 \mathrm{~mm}$. S. latifolia A.C.Sm.; Guyana, M. Jansen et al. 5662 (Uw 30535), 45 mm. S. standleyi Lundell; Panama, M. Nee 9472 (MADw 32560), 51 $\mathrm{mm}$. S. venezuelana Mez; Venezuela, L. Williams 11984 (MADw 34251), mature. Synardisia venosa (Donn.Sm.) Lundell; Mexico, D. Breedlove 15400 (MADw 23969), $60 \mathrm{~mm}$. Tapeinosperma nectandroides Mez; New Caledonia, P. Sarlin 132 (Tw 30578), 12 mm. Theophrasta americana L.; Dominican Republic: Hispaniola, W.L. Abbott s.n. (SJRw 7447), 30 mm. Wallenia grisebachii Mez; Jamaica, Miller 1365 (MADw 20765), 40 mm. W. laurifolia Sw.; Dominican Republic, Abbott 2519 (MADw 19894), $42 \mathrm{~mm}$. 